\title{
Public Pension Promises: How Big Are They and What Are They Worth?*
}

\author{
Robert Novy-Marx \\ University of Chicago Booth School of Business and NBER \\ Joshua D. Rauh \\ Kellogg School of Management and NBER
}

December 18, 2009

\begin{abstract}
We calculate two present value measures of already-promised state pension liabilities using discount rates that reflect the risk of the payments from a taxpayer perspective under different conditions. If benefits have the same default and recovery characteristics as general obligation debt, liabilities across all 50 states amount to $\$ 3.21$ trillion. This calculation probably understates the liability, because pension promises typically have higher priority than state municipal debt. Using zero-coupon Treasury yields, which are default-free but contain other priced risks that may not be relevant for pension liabilities, total liabilities are $\$ 5.20$ trillion. Liabilities are even larger under broader concepts that account for projected salary growth and future service.
\end{abstract}

\footnotetext{
* Novy-Marx: (773) 834-7123, rnm@ ChicagoBooth.edu. Rauh: (847) 491-4462, joshua-rauh@kellogg.northwestern.edu. We thank Jeffrey Brown, Jeremy Gold, Deborah Lucas, Olivia Mitchell, Eduard Ponds, James Poterba, and Steve Zeldes for helpful discussions and comments. We also thank seminar participants at the National Tax Association Conference on Attaining Fiscal Sustainability (September 2008), Wharton Department of Risk and Insurance, the Netspar Pension Workshop (January 2009), the MIT Bradley Public Economics seminar, the Society of Actuaries Public Pension Finance Symposium (May 2009), the June 2009 ICPM Discussion Forum, and the Western Finance Association Meetings (San Diego 2009). We are grateful to Adam Friedlan and Jerry Chao for research assistance. We thank the Global Association of Risk Professionals (GARP) Risk Management Research Program, Netspar, and the Chicago Booth Initiative on Global Markets (IGM) for financial support.
} 
Government accounting rules currently obscure the magnitude of public pension liabilities in the United States. In particular, Government Accounting Standards Board (GASB) ruling 25 and Actuarial Standards of Practice (ASOP) item 27 stipulate that public pension liabilities are to be discounted at the expected rate of return on pension assets. This procedure creates a major potential bias in the measurement of public pension liabilities. Discounting liabilities at an expected rate of return on the assets in the plan runs counter to the entire logic of financial economics: financial streams of payment should be discounted at a rate that reflects their risk (Modigliani and Miller (1958)), and in particular their covariance with priced risks (Treynor (1961), Sharpe (1964), Lintner (1965)). This paper evaluates the economic magnitude of state public pension liabilities by applying financial valuation to the pension liabilities of U.S. states, using appropriate discount rates.

From a unique database on 116 state government pension plans built from government reports, we compile information on defined benefit (DB) assets and liabilities as reported by state governments. We then model the prospective stream of payments from state pension promises using each state's stated liability, discount rate, and actuarial cost method, as well as information on benefit formulas, the numbers and average wages of state employees by age and service, salary growth assumptions by age, mortality assumptions, cost of living adjustments (COLAs), and separation (job leaving) probabilities by age. We discount these payments at rates that reflect their risk from the perspective of taxpayers.

We begin by focusing only on payments that have already been promised and accrued. In other words, even if the pension plans could be completely frozen, states would still contractually owe these benefits. This quantity is known as an Accumulated Benefit Obligation (ABO) or termination liability. The ABO is not affected by uncertainty about future wages and service, as the cash flows associated with the $\mathrm{ABO}$ are based completely on information known today: plan benefit formulas, current salaries and current years of service. ${ }^{1}$ As we explain later, different states use different methods to calculate accrued liabilities. Our model of prospective payments allows us to calculate the ABO for each state.

We first calculate a measure of the taxpayer obligation represented by these accumulated state pension liabilities under the assumption that accrued state pension benefits have the same priority as state general obligation (GO) debt. This assumption implies a discount rate for each payment equal to the state's own zero-coupon bond yield corrected for the tax preference on municipal debt (which we call the "taxable muni rate"). Under this measure, public pension liabilities are $\$ 3.21$ trillion, which is larger than the $\$ 2.98$ trillion obtained by summing the unadjusted liabilities from state government reports. The harmonization of the liabilities to the $\mathrm{ABO}$ method actually reduces the liability slightly, since most states use a slightly broader measure, but the application of the appropriate discount rates raises liabilities.

\footnotetext{
${ }^{1}$ One source of uncertainty that might affect the ABO is inflation. We discuss this effect in Section V.
} 
This \$3.21 trillion calculation recognizes the possibility that plan participants, including those already retired and receiving benefits, may not receive the full amount of promised benefits in the future. From the perspective of the taxpayer, assuming that pension liabilities are as risky as state GO debt credits states for their ability to default on pension promises. The use of the taxable muni rate for discounting assumes that these pension defaults would happen in the same states of the world as muni defaults, and that beneficiaries would eventually receive payments proportional to the recovery rates enjoyed by the municipal bond investors.

Crediting state governments by reducing pension liabilities based on GO default premiums probably leads to an understatement of the liability to the taxpayer. Most importantly, state constitutions generally offer protections to benefits that go above and beyond protections to state GO debt (Brown and Wilcox (2009)). The higher priority accorded to public pension cash flows suggests that they should be discounted at rates lower than the state GO bond yield. In most states, a pension default is less likely than a GO debt default. Even if states were to default on pension promises, the law suggests that the pension obligations should have a higher recovery rate than GO debt. Somewhat offsetting this is the possibility that states might receive a bailout from the federal government for these pension promises, in which case taxpayers of a given state might view the pension liabilities as less certain. However, because our focus is on an aggregate liability calculation across 50 states, this issue would affect the distribution of liabilities across states but not the total liability to all US taxpayers.

The second main measure we present is a measure that attempts to view the liability as default free. Given the protections that state constitutions provide to accrued public pension promises, beneficiaries face a negligible probability of default on benefits they have already earned. Thus, using some type of default-free yield curve would be appropriate to measure the liability if we were doing so from the perspective of beneficiaries. If taxpayers are the ultimate underwriters of the default-free promise, then this calculation also values the liability from their perspective. The approximation we use for the default-free curve is the Treasury zero-coupon yield curve. Under the Treasury-discounting measure of liabilities, total liabilities are $\$ 5.20$ trillion.

There are important caveats about using the Treasury yield curve as a measure of risk in a default-free pension liability. Although the Treasury yield curve is generally viewed as default-free, it reflects other risks that may not be present in the pension liability. State employee pensions typically contain COLAs. If inflation risk is priced (Fisher (1975), Barro (1976), Benninga and Protopapadakis (1985)), then an appropriate default-free pension discount rate would involve a downward adjustment of nominal yields to remove the inflation risk premium. This adjustment would further increase the present value of ABO liabilities. However, a countervailing factor is the fact that Treasuries trade at a premium due to their liquidity (Woodford (1990), Duffie and Singleton (1997), Longstaff (2004), Krishnamurthy 
and Vissing-Jorgensen (2008)). Pension obligations are nowhere near as liquid as Treasuries. Therefore a liquidity price premium should ideally be removed from Treasury rates before using them to discount default-free but illiquid obligations. Given the lack of consensus over the relative size of the liquidity price premium and inflation yield premium, we use unadjusted Treasury rates to calculate our default-free liability measures. However, we note that due to these risks priced into the Treasury curve, default-free public pension obligations are not equivalent to Treasuries.

States set aside assets in pension funds that are dedicated to providing the retirement benefit cash flows associated with these liabilities. As of the end of 2008, the states had approximately $\$ 1.94$ trillion in assets in the plans we study. The difference between assets and liabilities is therefore $\$ 1.27$ trillion under taxable muni discounting and $\$ 3.26$ trillion under Treasury discounting. In this paper, we do not address the question of optimal funding levels, which is separate from the valuation question.

The calculations above use the ABO, a very narrow measure of liabilities in that it considers the accrued liability to be only what is implied by current salary and years of service. In a typical plan, a worker accrues the right to an annual benefit upon retirement that equals a flat percentage of his final (or late-career) salary times his years of service with the employer. If salary increases with years of service for a given worker, the worker's ABO grows convexly with years of service. Thus, the ABO delays a large share of recognized liabilities until late in the employee's life. The newly accrued liability under the $\mathrm{ABO}$ rises dramatically as a fraction of the worker's salary as he approaches retirement.

There is substantial debate as to whether the ABO is the most meaningful liability measure or whether more of the liability owing to future salary growth and years of service should be recognized up front (Treynor (1976), Bulow (1982), Bodie (1990)). A broader measure than the ABO is the Projected Benefit Obligation (PBO), which takes projected future salary increases into account in calculating today's liability, but not future years of service. An even broader concept is the Projected Value of Benefits (PVB), which discounts a full projection of what current employees are expected to be owed if their salary grows and they retire according to actuarial assumptions.

The fact that states cannot freeze pension accruals as easily as companies may argue for considering a liability measure broader than the $\mathrm{ABO}$ in the state pension context. If states had no ability to limit future pension accruals, the $\mathrm{ABO}$ would seem to be an excessively narrow measure. However, Bulow (1982) explains that the broader measures only make sense if the implicit labor contracts involve overpaying old workers at the expense of young ones. If labor markets are competitive, there should be no misalignments between the marginal product of labor and total compensation. ${ }^{2}$

\footnotetext{
${ }^{2}$ Furthermore, Bulow (1982) argues that even if labor markets fail to be competitive, there could be other implicit contract liabilities that are larger when the PBO is smaller. If that is the case then the PBO is not a good measure of the employer's total implicit contract liability.
} 
The actuarial methods used by states are not classified as ABO or PBO. Most states report accrued actuarial liabilities under the so-called Entry Age Normal (EAN) method, in which new service liabilities accrue as a fixed percentage of a given worker's salary throughout his or her career. The EAN is therefore a measure between the PBO and the PVB. Finally, approximately $15 \%$ of liabilities are calculated using the so-called Projected Unit Credit (PUC) method, which is typically implemented to yield a PBO.

To calculate our main numbers, we implement calibrations to translate the stated EAN or PUC liability measures into an $\mathrm{ABO}$ for each state pension plan. In addition to the $\mathrm{ABO}$ measures, we also calculate the present value of PBO, EAN, and PVB liabilities. These broader measures have the additional complication that their evolution depends on the path of future government wages, which may be correlated with pricing factors, such as stock market returns, over long horizons. If this is the case, the streams of payments in the broader liability measures (at least those above and beyond the ABO) should be discounted at higher rates to reflect this systematic risk. Acknowledging that government wages and the stock market may be correlated at long horizons that are not observed, we see little evidence of this sort of correlation in the data. However, in order to be conservative, we calculate the broader measures under discount rates that reflect high correlations between government worker salaries and the stock market.

We emphasize that considerations about the accrual method affect only the liability for active workers, whom we calculate are responsible for only around one-third of the total liability. The rest of the liability comes from retired and separated workers. The accrual standards differ only in their treatment of uncertainty about future wages and years of service. Therefore, for annuitants (i.e., retirees) and former employees entitled to future benefits, the liabilities are the same under the different actuarial standards.

Our valuation methodology uses the entire yield curve. It does not rely on a single average measure of public pension liability duration. It can therefore handle tilts to the yield curve as well as parallel shifts in yield. Our model of the stream of promised pension payments nonetheless lends new insight into the duration and convexity of state public pension liabilities overall and of their constituent components (active, separated, and retired workers). Measurements of the duration and convexity of the liabilities facilitate understanding the impact of changes in market-based rates on the present value of liabilities. The effective average duration over the range of discount rates we consider is roughly 15 years, which is similar to the durations typically assumed for public pension liabilities (Barclays Global Investors (2004), Waring (2004a, 2004b)). However, our analysis shows that there is a great deal of convexity in the promised pension payments, as well as large differences in duration between liabilities posed by active, separated and retired workers. 
Our calculations refer to liabilities that have been accrued already under these different measures. They ignore the question of whether states have sufficient tax revenues to fund the flow of newly accrued liabilities. They also ignore other postretirement employee benefits (OPEBs), including state-provided retiree healthcare, which total $\$ 380$ billion in present value according to recent disclosures (Pew Charitable Trust (2007)). Furthermore, we focus only on state pension plans, not local city and county plans, whose size is about $20 \%$ of state plans. ${ }^{3}$ Therefore, our calculations certainly understate total liabilities related to pension and other retirement benefits offered by U.S. state and local governments. We note that the liabilities of state employee pension systems are larger than the liabilities faced by the federal government through exposure to corporate pension plans. Total ABO liabilities of all PBGCcovered DB plans were \$1.6 trillion at the latest estimate in 2003 (Congressional Budget Office (2005)).

Questions of risk and liability discounting similar to those we address have arisen in the measurement of Social Security liabilities (Geanakoplos and Zeldes (2009a, 2009b), Geanakoplos, Mitchell, and Zeldes (1999), Blocker, Kotlikoff and Ross (2008)). Geanakoplos and Zeldes (2009a) derive a market value of Social Security promises by considering a system of personal accounts that could be structured to exactly replicate promised Social Security payments under the current system. Our approach to valuing public pension liabilities is similar in that we price the promised cash flow streams from state employee pensions. However, since Social Security is wage-indexed, even the Social Security $\mathrm{ABO}$ depends on future labor earnings, whereas for state employee pensions the ABO does not depend on future wage growth.

The paper proceeds as follows. Section I takes state disclosures of liabilities as given and, as a starting point for our analysis, calculates aggregate US state pension plan liabilities on this reporting basis. Section II outlines the different liability concepts: ABO, PBO, EAN, and PVB in increasing order of broadness. In Section III we implement calibrations to translate among different liability measures for a given discount rate. We calculate what liabilities would be under the different accrual concepts, but still under state-chosen discount rates. Section IV calculates the value of ABO pension liabilities under appropriate discount rates. Section V discusses the duration and convexity of outstanding state pension promises as implied by our calibration. Section VI considers broader liability measures. We also analyze the effects of correlations between government wages and the stock market on these measures. Section VII concludes.

\footnotetext{
${ }^{3}$ According to the U.S. Census of Governments, local plans in aggregate held $\$ 0.56$ trillion in assets as of June 2007 , which is about $20 \%$ of what state pension plan assets were at the time. According to Pensions and Investments, as of September 2008 the largest of these local plans were New York City (\$93 billion in assets), Los Angeles County ( $\$ 35$ billion in assets), and San Francisco County ( $\$ 14$ billion in assets). If the ratio of assets to liabilities were the same as in state plans, local plan liabilities would be $\$ 0.93$ trillion under the taxable muni discounting and $\$ 1.50$ trillion under the Treasury discounting.
} 


\section{State Pension Liabilities Under Current Reporting}

In a typical DB pension plan, an employer pledges an annual pension payment of an amount that is a function of the employee's final salary and years of employment. Most states have at least one DB plan for teachers and another for general state employees. Some states have one combined plan for all state employees. Many have a number of smaller plans.

While the US corporate sector has moved away from DB plans and towards defined contribution (DC) arrangements such as $401(\mathrm{k})$ plans, the public sector has seen very limited movement in this direction. A March 2008 Bureau of Labor Statistics (BLS) survey indicates that $80 \%$ of state and local government workers are enrolled in a DB plan and under 20\% are enrolled in a DC plan (Bureau of Labor Statistics (2008)). The Government Accounting Office (GAO) reported in late 2007 that only Alaska and Michigan offered new employees in their "primary pension plan" a DC arrangement but not a DB arrangement, while Indiana and Oregon offered a hybrid plan; all other states offered only DB plans to new employees in their primary plan (Government Accounting Office (2007)). ${ }^{4}$ Finally, according to data from the Pensions and Investments (P\&I) survey of the 1000 largest pension plans, 32 states reported nonzero defined contribution (DC) assets in a state-sponsored pension plan. However, the total magnitude of DC assets was $\$ 83$ billion compared to $\$ 2.30$ trillion in DB assets.

We collected data on the largest DB pension funds sponsored by U.S. state governments. To assemble the list of plans, we began with data from the U.S. Census of Governments (2007), published by the U.S. Census Department. We listed all plans with more than $\$ 1$ billion of assets, including only those plans sponsored by state governments themselves.

The Census of Governments does not contain measures of pension liabilities. We therefore examined the most recent Comprehensive Annual Financial Report (CAFR) for each pension plan and collected total actuarial liabilities for each pension plan, along with the discount rate used by state actuaries to calculate these liabilities. In some cases, the Census of Governments had aggregated plans that we found to have separate CAFRs, or separate disclosures within a CAFR. Disaggregating as much as possible, we identified 116 individual state plans at the end of 2008. The statement of liabilities in the CAFRs is an accrued actuarial liability (AAL). In calculating an AAL, state actuaries must begin with a projection of the expected streams of payments that will be made to current and former employees. Since benefits typically depend on an employee's ultimate years of service and his salary late in his career, some of those expected benefits will not yet have been earned or "accrued" by the worker. Actuaries therefore have to determine the allocation of the present value of liabilities to past, current, and future

\footnotetext{
${ }^{4}$ Nebraska offered a cash balance plan, a type of DB plan in which the value of the plan is presented to employees as a cash balance and the trajectory of benefit accrual with respect to tenure is more concave than in a traditional DB plan.
} 
years. The flow measure of accruing benefits is called the Normal Cost, which is the share of the present value of future benefits assigned to a given year. The AAL is the portion of the present value of benefits which is not going to be reflected in future normal costs.

In Section II we will consider the subtlety of what pension promises are recognized in the stated liability. For now, we point out that this consideration matters only for the part of liabilities attributed to the current workforce, since all benefit promises to retired and otherwise separated workers have already been made based on the past work of those former employees.

The actuaries also need to choose a discount rate with which to discount the future payments from these accrued benefits. For our 116 sample plans, we were able to locate 102 disclosures of discount rate assumptions. The discount rates used by the state plans to calculate these liabilities had a mean of 7.97\% with a standard deviation of $0.36 \%$ and a median of $8.00 \%$. The modal discount rate was also $8.00 \%$ with 45 entities using this rate. The minimum rate was $7.00 \%$ and the maximum was $8.5 \% .{ }^{5}$

We begin by taking the AAL calculations as reported, and then consider how different AAL methods and discount rates might affect them. A simple sum of stated liabilities over our 116 plans yields $\$ 2.84$ trillion in liabilities. However, the latest actuarial measurement dates vary by plan, and may not be as recent as the reporting date for the assets. ${ }^{6}$ We project liabilities forward to 2008 by assuming a $6 \%$ annual growth rate, consistent with the growth rate observed in the data for the plans with both 2007 and 2008 valuations. This yields $\$ 2.98$ trillion in aggregate AAL liabilities as of 2008 .

For comparison, we also estimated total assets in these plans as of the end of 2008. Internet Appendix Table I shows that of the 116 CAFRs, 66 were for the year ended 30 June 2008, 16 were for the year ended 31 December 2007, 22 were for the year ended 30 June 2007, and 12 were as of another date between June 2007 and September 2008. The dates were therefore heterogeneous, in some cases old, and in all cases before the massive market declines of late 2008. We therefore used two distinct methods based to project assets forward from these heterogeneous dates through to December 2008. As explained in Internet Technical Appendix 1, these two methods both rely on measuring asset allocation to a set of asset classes and projecting assets forward using asset class returns. ${ }^{7}$ They yield essentially identical results, giving us a preferred estimate of $\$ 1.94$ trillion in assets.

\footnotetext{
${ }^{5}$ Giertz and Papke (2007) find some evidence that these assumptions are manipulated to reduce pressure on governments to make contributions to pension funds.

${ }^{6}$ Only 41 plans reported an actuarial value of liabilities for 2008. For 69 plans, the latest valuation was from 2007, and for the remaining 6 the latest valuation was from 2006.

${ }^{7}$ The asset allocation figures are shown in Internet Appendix Table II. They bear similarity to the tabulations in Rauh (2009) of corporate pension plans, in which total allocations to equity among major pension sponsors as of the end of 2003 were approximately $60 \%$. Our analysis assumed that public pension plans do not generate negative alpha, i.e., that they do not perform worse than the market benchmark. Coronado, Engen and Knight (2003) find that public plans earned a significantly lower rate of return than private plans during the period they analyze. Yang and Mitchell (2006) find that certain governance structures can enhance public pension plan investment performance.
} 
Taking the pension liability calculations from the state plans as reported, there is an aggregate difference between liabilities and assets of \$1.04 trillion $(=\$ 2.98$ trillion in liabilities $-\$ 1.94$ trillion in assets). Similar "as-reported" calculations for previous years have also been performed by the Pew Charitable Trust (2007), National Association of Retirement Administrators (2003-2007), Merrill Lynch Research (2007), and Munnell et al (2008a, 2008b). On average for these studies, the difference between assets and liabilities was closer to $\$ 0.3$ trillion, due to higher asset values before the market decline of 2008.

In the following sections, we will see that these calculations based on liabilities taken verbatim from the reports substantially understate the value of public pension liabilities.

\section{Liability Concepts for State Pension Promises}

One issue that arises in calculating the present value of pension liabilities is the question of how and to what extent pension benefits owed in the future should be recognized today ((Treynor (1976), Bulow (1982), Bodie (1990)). In this section we discuss several accrual methods for active workers. In Section III we will show stylized examples of these various liability concepts, and we present calculations of actual state pension liabilities under the different methods.

\section{A. The Accumulated Benefit Obligation (ABO)}

In a typical plan, an active worker accrues the right to an annual benefit upon retirement that equals a flat percentage of his final (or late-career) salary times his years of service with the employer. So for example, suppose the benefit factor is $2 \%$ and Alice has worked for 10 years and has an average wage in the last several years of work equal to $\$ 40,000$. Alice will be entitled to a pension of $\$ 8,000$ (= $2 \% * 10 * \$ 40,000)$ per annum when she retires, plus any COLAs her plan offers. Suppose that Bob has worked for 20 years and has an average wage in the last several years of work equal to $\$ 60,000$. He is entitled to a benefit when he retires of $\$ 24,000(=2 \% * 20 * \$ 60,000)$ plus any COLAs. COLAs vary by state by plan but typically index the annual payment to a fixed rate of inflation (e.g. $3 \%$ ) or to the Consumer Price Index (see Peng (2009)). Note that for a given worker, both the years of service and the salary will grow with each year of work, so that the nominal benefit the worker expects to receive increases convexly with their age.

Consider a plan in which both Alice and Bob are just days before reaching their retirement age of 65. In this plan, it seems clear that the sponsor's financial liability is the present value of one annuity that will pay Alice $\$ 8,000$ until she dies, and one that will pay Bob $\$ 24,000$ until he dies, both adjusted for the COLAs specified by the plan. To value this, one only needs mortality tables that project how long Alice and Bob will live starting at 65 years of age, inflation assumptions, and appropriate discount rates. 
Now consider instead a plan in which Alice and Bob are both 45 years old but have both quit the workforce. In actuarial terms, they are called "separated" workers. What is the present value of this promise? The liability is again a present value of Alice's annuity of $\$ 8,000$ and Bob's annuity of $\$ 24,000$, but the annuities do not need to begin for 20 years. Setting aside the important matter of selecting the discount rate, the state's liability here is still clear. It is the expected value of these annuities discounted by 20 years (the amount of time before Alice and Bob reach the retirement age). Again, the state only needs mortality tables and inflation assumptions, although here the tables need to start at the latest at 45 years of age and the inflation assumptions need to run further into the future.

Now instead consider a plan in which Alice and Bob are both 45 years old and both working. Here the sponsor's financial liability is not as obvious. If the state views the liability as though Alice and Bob were going to stop working today, it is behaving as though it could stop the benefit accrual to Alice and Bob at any time by freezing (terminating) the pension plan. This method is the Accumulated Benefit Obligation (ABO) measure, or termination liability. Under a termination liability, the sponsor does not worry about the fact that as Alice and Bob get older, their ABO liability grows convexly with additional years of service. Calculating an $\mathrm{ABO}$ is relatively simple, as beyond the mortality tables, one needs only the benefit formula, the current wages of the employees by years of service, and inflation assumptions. To calculate a plan's total ABO, one simply adds up the ABOs represented by each individual employee. This adding up requires the distribution of plan employees by age and service (an "age-service matrix"), as well as average wages of state employees by age and service.

If workers receive their marginal product in total compensation (wages plus pension benefits), the $\mathrm{ABO}$ is the correct concept since it measures the benefits that employees have actually earned (Bulow (1982), Brown and Wilcox (2009)). The ABO is also narrow in that it does not recognize any future wage increases or future service that employees are expected to provide, even though such wage increases and service are to some extent predictable. Moreover, the ABO obligation is also independent of wage risk, which simplifies the valuation. Consequently, our main estimates of state pension liabilities employ this accrual method, as it represents a conservative appraisal of states' financial obligations to public employee pensions.

However, since the employer is a state government, it may not be valid to assume that the sponsor can completely stop the employees' pension accrual at will, as is implicitly assumed in the ABO. This inability to freeze matters if state employees will be overpaid in the future relative to their future marginal product - which seems possible since casual observation suggests a willingness by public employees to accept low salaries today in exchange for job security. ${ }^{8}$ The future overcompensation, which may be in the form of rapidly accruing pension benefits, then represents a current financial liability. Such

\footnotetext{
${ }^{8}$ See also footnote 3 for a further caveat.
} 
considerations suggest the use of broader liability measures that reflect expected future wage increases and/or years of service. ${ }^{9}$ The states themselves also typically report their pension liabilities using measures that are broader than the ABO. These facts lead us to consider some broader liability measures.

\section{B. The Projected Value of Benefits (PVB)}

A very broad way to measure pension liabilities would be to demand that actuaries begin with the full projection of what current employees are expected to be owed if their salary grows and they continue working, retire and die according to actuarial assumptions. One could then discount those payments and arrive at a broad present value liability. To make such projections, one needs two additional ingredients beyond those employed in the ABO calculation: salary growth assumptions by age, and separation probabilities by age.

If a vested worker of age $a$ and service $s$ separates this year, her PVB is equal to her ABO, because she will not earn any more benefits. Superscripting the years until separation and subscripting age (a) and service $(s)$, we write:

$$
P V B_{a, s}^{0}=A B O_{a, s}^{0}=\left[\min (\alpha \times s, 1) \times W_{a, s}\right] \times A_{a}
$$

where $W_{a, s}$ is the worker's annual wages, $\alpha$ is the benefit factor so that $\min (\alpha \times s, 1)$ is the fraction of these wages she will receive, and $A_{a}$ is the annuity factor for a worker of age $a$ receiving cost of living adjusted benefits every year until death, starting no earlier than the year after they turn 65 . This annuity factor is equal to

$$
A_{a}=\sum_{i=\max (65-a, 0)+1}^{\infty}\left(\frac{1+\text { cola }}{1+r}\right)^{i} S_{a, i}
$$

where $S_{a, i}$ is the probability of surviving from age $a$ to age $a+i$.

The PVB of a worker separating $T$ years in the future is the value, discounted both for time and mortality, of the expected obligation at the time of separation,

$$
P V B_{a, s}^{T}=\frac{S_{a, T}}{(1+r)^{T}} \times \mathbf{E}\left[P V B_{a+T, S+T}^{0}\right]
$$

The unconditional PVB for an employee of age $a$ with $s$ years of service is the expectation, over years until separation, of the PVB conditional on years until separation.

The PVB method is extreme because it does not credit the state for the fact that it might have some ability to limit benefit accruals, even if it cannot stop them completely at will. It also requires that we recognize today liabilities that are due to employees' future service. Of course, one could consider an

\footnotetext{
${ }^{9}$ Furthermore, if pensions are considered part of a compensation package which consists optimally of current and deferred components, there may be additional contractual reasons for the firm to consider a broadly defined pension liability (Lucas and Zeldes (2006)).
} 
even broader concept that assessed benefits expected to accrue in the future to workers who have not yet been hired.

\section{Entry Age Normal (EAN) and Projected Benefit Obligation (PBO)}

All of our 116 state plans report liabilities using an actuarial method that recognizes more than the ABO liability but less than the PVB liability. Entry age normal (EAN) is the dominant method employed by our 116 state plans. Matching our dataset to that of the Boston College Center for Retirement Research (2006), we find that approximately $68 \%$ of the liabilities in the CAFRs are calculated on a EAN basis, and an additional $17 \%$ use closely related methods. The remaining $15 \%$ of liabilities are stated using an actuarial method called projected unit credit (PUC), which as implemented by the states yields the projected benefit obligation (PBO).

Both the EAN and PBO recognize a fraction of the PVB (Winklevoss (1993), Lenze (2009)). The PBO method recognizes the PVB prorated by service:

$$
P B O_{a, s}^{T}=\left(\frac{s}{s+T}\right) \times P V B_{a, s}^{T} .
$$

That is, the PBO projects future wage growth, but does not recognize future service. For a comparison of the ABO and PBO in a corporate pension context, see Bodie (1990).

The EAN method recognizes the PVB in proportion to discounted wages earned to date relative to discounted expected lifetime wages:

$$
\operatorname{EAN}_{a, s}^{T}=\left(\frac{\sum_{i=1}^{s} \frac{S_{a-s, i}}{(1+r)^{i}} \times W_{a-s+i, i}}{\sum_{i=1}^{s+T} \frac{S_{a-s, i}}{(1+r)^{i}} \times W_{a-s+i, i}}\right) \times P V B_{a, s}^{T}
$$

where wages are discounted to reflect both the time value of money and mortality rates. Under the EAN method, the normal cost (the annual growth in the liability due to new service) is a constant percentage of a worker's salary. The EAN may consequently be interpreted as estimating the percentage of employees' wages that would have to be set aside to meet retirement benefits, under the implicit assumption that the savings can be invested risk-free at the discount rate used to value the liabilities. This accrual method therefore resembles a DC plan in which participants do not bear investment risk, since contributing a constant fraction of salary is similar to how many individuals without a DB pension plan save for their own retirement. ${ }^{10}$

Provided wages grow slower than the discount rate that reflects the time value of money and mortality rates, the EAN always exceeds the PBO. The EAN is often therefore interpreted as recognizing some future service. Both the EAN and the PBO exceed the ABO, and both are smaller than the PVB. The four measures converge at retirement, requiring the methods that recognize less of the liability early

\footnotetext{
${ }^{10}$ See Internet Appendix Technical Note 2 for more details.
} 
on to have larger accruals close to retirement. If an individual tried to save for retirement in a way that mimicked an $\mathrm{ABO}$, he would have to save a much higher fraction of his salary later in life than earlier in his life.

\section{Accrual Methods are Irrelevant for Annuitants and Separated Workers}

All the accrual methods treat separated workers in the same way. In every case the obligation posed by separated workers - both those currently receiving benefits and those that have not yet started collecting - are recognized on the same basis. The liability of a separated worker is the present value of the benefits that they are expected to receive, where the present values are calculated using the plan's discount rate. This is just the annuitized value of the annual benefit that they are currently receiving, or in the case of workers not yet eligible for benefits, the annual benefit they would receive if they were currently eligible.

E. An Example

Figure 1 illustrates the different accrual concepts using a simplified set of assumptions. In particular, the figure shows the liabilities represented by workers age 21 to 65 , hired at age 20 and retiring at age 65 . It assumes wages are consistent with the wage growth by age and service assumptions derived from the state CAFRs (as will be explained in the following section). The figure also uses an assumed $3.5 \%$ expected inflation rate (the states' modal assumption), and calibrates to an income of $\$ 100,000$ by a 65 year old worker with 45 years of service. Other model inputs for this figure are close to the averages of those actually employed by the states: a $\%$ benefit formula, a 3\% COLA, an 8\% discount rate, and mortality rates taken from the RP2000 combined mortality table.

The figure illustrates three salient features of the different methodologies. First, the three nonPVB methods start at zero because employees have no years of service; the PVB starts at a positive level because it recognizes liabilities from future years of service. Second, all four measures converge to the same value at retirement. Third, the rank ordering of the accrual methods from narrowest to broadest is: ABO, PBO, EAN, PVB.

Note that the figure depicts liabilities represented by active workers, and thus shows significantly more variation across accounting measures than there is in total liabilities. All four accounting methods treat retired and separated workers symmetrically, and these workers represent roughly two-thirds of aggregate state pension liabilities. Total aggregate liabilities accounting for all claimants are consequently more similar under different accounting measures than suggested by the figure.

\section{Calculating State Pension Liabilities Under Different Accrual Methods}

To calculate state pension liabilities under the different accrual concepts, we use the following procedure. We begin with a five-item array for each of the 116 plans that includes: 1.) the plan's stated 
liability; 2.) its state-chosen discount rate; 3.) the actuarial method (EAN or PUC) employed by the state to calculate the liabilities; 4.) the share of active workers in the plan; and 5.) the share of retired workers in the plan. ${ }^{11}$ The stated liability and discount rate come from our own data collection described in Section I. The actuarial method combines our own data collection with information from the state and local pension data made available by the Center for Retirement Research (2006).

We then convert this five-item array for each state into a modeled stream of payments that would yield the reported liabilities if discounted using the reported discount rate. This calculation requires several matrices that pin down assumptions about salaries, years of service, and separation probabilities by age for active workers. In particular, we require a vector of salary growth by age; a vector of separation probabilities by age; the distribution of plan participants by age and years of service (an "ageservice matrix"), and the average wages of employees in each cell. To derive these inputs, we examined the CAFRs of the 10 states with the largest total liabilities and took the assumptions from the reports where they were usable: New York, Illinois, Pennsylvania, Ohio, and Texas. The matrices we use are an average over the reports. These matrices are provided in Internet Appendix Table III.

We also require several additional technical assumptions, specifically: i.) a benefit formula, which we assume to be a constant fixed fraction of salary times years of service, with employees vesting after five years service; ii.) a cost of living adjustment (COLA); iii.) an inflation assumption, which we require to estimate the benefits of annuitants; iv.) a vector of mortality assumptions by age, for which we use the RP2000 combined mortality table used by many states; and v.) an age at which beneficiaries can begin receiving full benefits, which we take to be $62 .{ }^{12}$ We could allow younger retirees to receive benefits prior to turning 62, but assuming retirement benefits are adjusted in an actuarially fair manner, this has no effect on our liability calculations. ${ }^{13}$

For the benefit formula, the COLA and the inflation assumption, we collected data on most plans from the CAFRs or from the Center for Retirement Research (2006). Table I summarizes the results of this data collection. For each of these items we were able to collect data for at least 90 of our 116 plans. Where data were unavailable, these items were ultimately filled in with sample means, but the table shows the data before that step. For 28 plans, benefit factors were given as a range, for which we picked the midpoint. For Cost of Living Adjustment (COLAs), the summary statistics shown are the COLA that we estimate are built into the states' nominal cash flow projections. The easiest case was if the COLA was fixed, in which case the COLA is just the fixed number given. If the COLAs were a CPI with a cap or

\footnotetext{
${ }^{11}$ The remaining workers in the plan are separated but not yet receiving benefits.

${ }^{12}$ This is an assumption calibrated to actual total benefit payments in 2005-2008. Actual total benefit payments were $\$ 153$ billion in 2008, and were growing at a rate of approximately $8 \%$. Setting retirement at 62 implies that actual total benefit payments would be $\$ 162$ billion in 2009 .

${ }^{13}$ By "actuarially fair," we mean that the employee's annual benefit is reduced such that the expected present value of lifetime payments equals the value of the life-time annuity that makes full payments beginning at age 62 .
} 
Partial CPI, the given formula was applied to the state's inflation assumption. If the COLA was ad hoc, excess earning, or other, we assumed the projected COLA equaled the state's inflation assumption.

If we were modeling liabilities "from scratch" (i.e., without knowing each plan's reported liability at state-chosen discount rates), the total liability would likely be quite sensitive to small changes in these assumptions. Crucially, however, we know both what the state is claiming its liability is and what discount rate it used to obtain that liability. We use our model to deliver the sensitivity of liabilities to discount rate variation $(-d \ln L / d r)$. This derivative is relatively insensitive to these additional assumptions.

Regarding retirees and separated workers, we have an approximate service distribution for them, based on disclosures in a subset of the CAFRs of the 10 states with the largest stated liabilities. We do not, however, have the distribution of their ages or benefit salaries. We consequently assume that annuitants are older than 62 , and that the distribution of their ages is consistent with mortality rates in the steady state. ${ }^{14}$ Because wages largely reflect service and not age, and average government wage growth (conditional on service) largely reflects inflation, we estimate the benefit salary of annuitants by adjusting the wages of currently employed workers with the same level of service to account for inflation and cost of living adjustments, under the assumption that the annuitant retired at 62. For workers who are separated and vested but not yet receiving benefits, we assume that their age distribution at each service level is the same as that for currently employed workers with the same level of service, and that their benefit wage is the wage of currently employed workers of the same age with the same service.

As a check of the model we consider how it performs replicating the states' aggregate reported liabilities "from scratch", without using the reported liabilities themselves. That is, we use the model to generate the stream of states' expected future pension payments, and then discount these at the average discount rate assumed by the states. Note that it is not important that our model-generated liability perfectly matches the reported liability. The purpose of modeling the stream of future pension payments is to investigate how the liability changes with discount rate assumptions, not to calculate its level. We know the level of states' reported liabilities, and can use them to calibrate the model.

To perform this check, we generate the expected future pension payments using the total number of active plan employees (12.29 million), their average salary $(\$ 41,830)$, the total numbers of annuitants and separated employees not yet receiving benefits (5.89 and 2.18 million, respectively), and the liability weighted average benefit factor $(2.03 \%)$, COLA $(2.86 \%)$ and inflation assumptions $(3.40 \%) .{ }^{15}$ We then

\footnotetext{
${ }^{14}$ For example, the mortality tables suggest that conditional on living to 62 there is roughly a $50 \%$ probability of living to 82, so we assume that there are twice as many annuitants of age 62 as there are of age 82 .

${ }^{15}$ The total number of active employees and average salaries are tabulated in the Internet Appendix. The average salary employed here is calculated by using the 2006 average salary for active plan participants of $\$ 39,859$, adjusted
} 
account for these payments on an 85.6\% EAN / 14.4\% PUC basis (the relative liability weights of plans using EAN-like and PUC accounting). We discount these payments using the states' liability-weighted average assumed discount rate (7.94\%). The model generates an aggregate liability of $\$ 2.99$ trillion. This number was produced without using the states' actual stated liabilities and is essentially equivalent to the $\$ 2.98$ trillion reported by the states themselves. This provides us with some confidence that our model reasonably approximates the cash flow projections of the states themselves.

Despite the fact that we generate accurate aggregate cash flows, not calibrating to stated liabilities would throw away state-level variation in all the elements of the five-item array described previously. The reported liability may well capture information where our state-level actuarial data are incomplete. In the last step of our procedure, we therefore calibrate the model plan by plan, using plan-specific information. That is, for each plan we calibrate the stream of modeled benefit payments so that it is consistent with the stated liability provided in its CAFR. Using information for each plan regarding its benefit formula, COLA and inflation assumption, we adjust the average wage level of the plan's employees so that its aggregate liability, calculated using its stated actuarial method and employing its stated discount rate assumption, matches its reported liability. This calibrated stream of benefit payments can then be used to calculate the plan's liability under any accounting methodology, using any discount rate (or yield curve), employing the formulas presented in Section II.

Figure 2 shows projected aggregate cash flows by state governments due to state pension promises to workers hired prior to today, as would be recognized under the four main accrual methods: ABO, PBO, EAN, and PVB. In the near future, aggregate expected annual cash flows are roughly $\$ 160$ billion under all four measures. These obligations rise over time, peaking at $\$ 280$ billion after 20 years (ABO), $\$ 300$ billion after 25 years (EAN and PBO) and more than $\$ 450$ billion after 40 years (PVB).

Figure 3 decomposes the cash flows into those owed to the different worker groups. These categories are assigned based on the participant's status as of the end of 2008. The top graph shows the projected future cash flows for workers who were still active in 2008; these cash flows depend on the accrual methodology. The bottom graph shows the cash flows for workers who were retired and separated as of 2008; these liabilities as discussed above do not depend on any particular accrual methodology. Initially all the cash flows go to workers who were already retired as of 2008. Cash flows going to these annuitants decrease each year, reflecting the expected mortality of these claimants. These cash flows become insignificant after 30 years, at which time the youngest of these workers are 95 years old. Cash flows going to separated workers initially increase each year, as more and more of these individuals reach the age at which they can claim benefits. These cash flows to separated workers continue to increase for (CPS) of the U.S. Census Department (1.74\% and 3.15\% respectively). 
roughly twenty years, at which point the decrease in cash flow due to these claimants' mortality more than offsets the increases due to new claimants reaching benefit age.

The portion of the cash flows due to active workers has a profile similar to that due separated workers, albeit with a later peak. It slopes upward initially, as more and more newly retired workers reach the age at which they can draw benefits. The projected cash flows going to currently active employees continue to increase until downward pressure from worker mortality exceeds upward pressure from those reaching benefit age. The peak occurs much later for PVB cash flows than for ABO, EAN or PBO. The PVB recognizes the full expected service and terminal salary of even the youngest workers, while the EAN and PBO recognize only a fraction of these, and the ABO recognizes only the current service and salary of these workers.

Table II shows total state pension liabilities without adjustments to the discount factor, but applying different liability concepts, using all the state-level variation. The first number in the table, $\$ 2.98$ trillion, represents the sum of reported liabilities from the 116 CAFRs, projected to 2008 as necessary. Although most of these liabilities are stated on an EAN basis, not all of them are. Therefore, this sum is "unharmonized", in that it represents the sum of liabilities under somewhat heterogeneous actuarial methods.

The next rows of the table show the ABO, PBO, EAN, and PVB liabilities, again without adjustments to the discount factor. The EAN is $\$ 2.98$ trillion, and at this degree of precision is not distinguishable from the aggregate reported liability. The PBO, the other measure occasionally employed by states, is $\$ 2.92$ trillion. The broadest measure is the PVB at $\$ 3.43$ trillion. The narrowest measure is the $\mathrm{ABO}$ at $\$ 2.80$ trillion.

The table also shows a decomposition into the three groups of plan members from which the liabilities arise: active participants, annuitants (i.e., retirees), and those separated but not yet receiving benefits. It highlights the fact that the latter two categories are insensitive to the choice of actuarial method since they do not depend on future salary or service outcomes. Only about $45 \%$ of the liability comes from the active participants in the broadest measure (PVB) and 33\% in the narrowest (ABO). Therefore, the impact of the different actuarial methods on total liabilities is somewhat muted.

\section{The Value of State ABO Pension Promises Under Appropriate Discount Rates}

In this section we discuss appropriate discount rates for the stream of payments arising from a state's ABO liability. A financial stream of payments should be discounted at a rate that reflects its risk (Modigliani and Miller (1958)), and in particular their covariance with priced risks (Treynor (1961), Sharpe (1964), Lintner (1965)). In Section II, we explained that the correct discount rate for the ABO should not reflect any wage or salary risk, because the ABO does not account for future wage growth. In 
this section we consider appropriate discount rates in light of the possibility of other priced risks, particularly default risk, and we calculate the present value of $\mathrm{ABO}$ liabilities under these discount rates.

As several studies have pointed out previously (see for example Barclays Global Investors (2004)), the $8 \%$ average discount rate used by state-sponsored pension plans is almost certainly too high. The discount rate assumptions come from the Government Accounting Standards Board (GASB) ruling 25, and Actuarial Standards of Practice (ASOP) item 27, which together stipulate that the actuarial value of pension liabilities should depend on the assumed return on pension plan assets. Most finance academics and practitioners view this rule as misguided (see Gold (2002) and Bader and Gold (2004)). Financial liabilities should be discounted using discount rates that are specific to the factor (or market) risk inherent in the liabilities. ${ }^{16}$ The way the liabilities are funded is irrelevant to their value.

Note that the government accounting treatment of pensions differs substantially from the treatment of corporate pension plan liabilities. Under FASB rules for corporate reporting, a PBO must be reported. For FASB purposes, the PBO must be discounted using a blended corporate bond yield. ${ }^{17}$

From the perspective of taxpayers who are concerned with how large taxes will have to be in the future to cover liabilities, it is important to consider default risk. One hint as to the appropriate discount rate that reflects default risk comes from state-specific GO credit ratings, to which yields on states' municipal GO bonds are closely related. If government pension liabilities default in the same states of the world as other government debt, and have the same recovery rates, then the discount rate should be closely related to municipal bond yields. The upper three lines in Figure 4 show zero-coupon yield curves for state $\mathrm{GO}$ bonds with $\mathrm{A}, \mathrm{AA}$, and AAA ratings, which we calculated by stripping par yield curves from Bloomberg. ${ }^{18}$ Our liability calculations additionally employ the AA+, AA-, A+ and A- curves for plans sponsored by states with those ratings, but for simplicity they are not shown in the figure. Twenty of our 116 plans are sponsored by states rated AAA, 76 by states rated AA (including AA+ or AA-), and 7 by states rated $\mathrm{A}$ (including $\mathrm{A}+$ ). Thirteen plans are sponsored by unrated states; for these plans we use the A- curve.

Suppose that a state wanted to defease its entire pension obligation by paying off the beneficiaries with a portfolio of bonds that generates the same stream of payments as the benefits and defaults in

\footnotetext{
${ }^{16}$ This point has been made in the context of corporate pension plans by Petersen (1996) and Ippolito (2002).

${ }^{17}$ For the purposes of determining mandatory contributions, corporate ABO liabilities must be disclosed in IRS form 5500 and discounted using Treasury yields. See Rauh (2006) and Bergstresser, Desai, and Rauh (2006) for more information. The Pension Protection Act of 2006 changed the corporate rules. It stipulated that the discount rate for the current liability reported on the IRS 5500 may not be more than 5 percent above and must not be more than 10 percent below a 4-year moving average of 30-year Treasury yields.

${ }^{18}$ Specifically, from Bloomberg we obtained AAA, AA+, AA-, A+, and A- par yield curves. We calculate the zerocoupon yield curves by constructing long-short portfolios of coupon bonds that generate a single payment at one date in the future. We then interpolate between AA+ and AA- to obtain an AA curve, and between $\mathrm{A}+$ and A- to obtain an A curve. Beyond a 30-year term, we assume a flat yield curve at the 30-year rate.
} 
exactly the same states of the world. The cost of the defeasance would be the market value of the bonds the state must deliver today. Unlike coupons on municipal bond debt, state pension benefits are not tax exempt for beneficiaries. Therefore, the state would need to deliver the beneficiaries taxable bonds that generate the same stream of payments as the benefits in all states of the world.

This leads us to consider our first discount rate candidate for a given pension-related cash flow: the yield on a zero-coupon state GO municipal bond with the same term as the payment, grossed up to eliminate the tax preference given to borrowing. In other words, for state $i$ at time $t$, the tax-corrected yield would be $r_{i t} /\left(1-\tau_{B}\right)$, where $\tau_{B}$ is a personal investor's marginal tax rate on interest income, and $r_{i t}$ is the yield on a zero-coupon state GO bond of comparable maturity. We refer to this rate as the "taxable muni rate."

A key input to this calculation is the value of $\tau_{B}$, the marginal tax rate on municipal bond investors. While the statutory rate is $35 \%$, a number of papers have looked at the implicit tax rates on prime-grade municipal bonds relative to taxable Treasury bonds. Most recently, Poterba and Verdugo (2008) document that over the 10 years from 1998-2007 the spread of Treasuries over municipal bonds has been in the range of $50 \mathrm{bp}$ to $139 \mathrm{bp}$, representing an implicit tax rate of between $14.9 \%$ and $30.0 \%$. Over the period from 1991 to December 2008, the average implicit tax rate was 26.3\%, and over 19972008 it was even lower.

Poterba and Verdugo (2008) assume the market believed municipal bonds were no more likely to default than Treasuries, an assumption that is clearly violated today. At various times during 2008, as well as on January 30, 2009, Treasuries traded at a premium to AAA municipal bonds. Based on the Poterba and Verdugo (2008) findings, we set $\tau_{\mathrm{B}}$ at $25 \%$. Our assumption is therefore equivalent to the notion that during the Poterba and Verdugo (2008) period, the default probabilities for AAA municipals equaled the default probability for Treasuries, even though that is no longer the case today.

The ABO liability discounted at the taxable muni rate captures some of the spirit of the FASB rules for corporate pension discounting. The FASB rule lets corporations discount pension obligations at high-grade corporate bond rates. Discounting state pension obligations at state bond rates bears some similarity in that the creditworthiness of the asset class (municipal or corporate bonds) plays a role. However, the FASB rules do not specify that firms use company-specific bond rates, whereas our measure for public plans is based on state-specific discount rates. ${ }^{19}$

\footnotetext{
${ }^{19}$ There are some additional important differences. First, FASB rules require firms to recognize the PBO, whereas we are focusing on the ABO. Second, a firm will owe little beyond the assets in the pension fund if the firm becomes insolvent, since the PBGC will take over the plan and become an unsecured creditor in bankruptcy. States are not insured by the PBGC, and even if the state defaults on its debt, there is a high likelihood that it will have to pay pensions.
} 
The taxable muni rate is appropriate if the state is equally likely to default on its pension obligations as it is to default on its other debt. State constitutions, however, often build in protections for government-sponsored pensions. Brown and Wilcox (2009) document that in the majority of the 50 U.S. states, public pension obligations are specially protected by state constitutions in ways that make membership in a pension plan an "enforceable contractual relationship." 20 These provisions seem to give special protection to accumulated pension benefits, above and beyond protections that municipal creditors have. Finally, they document that in local fiscal crises such as those of Orange County in the mid 1990s and New York City in the mid 1970s, DB pensions are usually preserved.

The Brown-Wilcox analysis suggests that the default probability of state public pension liabilities is generally lower than that of state GO debt, and that their priority (recovery rate in default) is higher. This seems especially true for the already-promised benefits represented by the ABO.

If state pension promises were truly default-free, meaning that pensioners would get the expected benefit in all states of the world, and taxpayers were the ultimate underwriters of this default-free promise, then from the perspective of taxpayers it would be correct to discount the cash flows at a defaultfree rate. Alternatively, discounting with a default-free rate would be a correct procedure for measuring the liability from the perspective of the beneficiaries, if their ABO liabilities are indeed protected (either by state constitutions or by a federal bailout) in all states of the world.

Our second discount rate candidate is therefore a zero-coupon Treasury rate with the same term as the cash flow in question. The dark line in Figure 4 shows the Treasury yield curve as of January 30 , 2009, which we calculated by stripping the par yield curve using the same procedure employed for the municipal curve.

There are a number of caveats to using Treasury yields in discounting a default-free pension promise. The zero-coupon Treasury yield may be thought of as consisting of four components: a riskless real interest rate, a market-expected rate of inflation, an inflation risk premium (Fisher (1975), Barro (1976), Benninga and Protopapadakis (1985)), and a liquidity premium (Woodford (1990), Duffie and Singleton (1997), Longstaff (2004), Krishnamurthy and Vissing-Jorgensen (2008)). Due to the inflation risk premium and liquidity premium, holders of long-dated Treasury bonds hold a default-free asset, but one that contains some other priced risks.

Treasury investors are exposed to inflation risk, because realized inflation determines the real value of the bond's payoffs. If inflation is correlated with pricing factors then this inflation risk will raise nominal Treasury yields. Buraschi and Jiltsov (2005) estimate an average ten-year inflation risk premium in Treasury bonds of 70 basis points over the period 1965-2005, ranging from 20bp to $140 \mathrm{bp}$ over the

\footnotetext{
${ }^{20}$ In other cases, state statutory and common law offer protections. See also National Conference on Public Employee Retirement Systems (2007).
} 
business cycle. If pension beneficiaries enjoy COLAs that fully remove inflation risk, one would want to adjust nominal Treasury yields downward for the full amount of this inflation risk premium. Therefore, to the extent that COLAs provide the beneficiaries with a partial hedge against inflation risk, nominal Treasury bond yields may be too high.

Treasury bond investors also may receive lower nominal yields because of the liquidity price premium that Treasury bonds enjoy. The liquidity price premium is small and positive on average, but displays a great deal of variation over time. Longstaff (2004) estimates a 10-15bp liquidity spread on average of Treasuries over U.S. non-Treasury debt with the same explicit government guarantees.

Krishnamurthy and Vissing-Jorgensen (2008) estimate that superior trading liquidity accounts on average for $50 \mathrm{bp}$ of the spread between Treasuries and AAA corporate bonds. Therefore, if there were no COLAs, it would be clear that one would want to adjust nominal Treasury yields upward for the purpose of calculating a default free pension liability.

We proceed using the Treasury yield curve to discount liabilities as an approximation to using a hypothetical default-free rate that does not contain priced inflation and liquidity risks. While the inflation and liquidity risk premiums typically go in opposite directions, we of course do not assert that they cancel each other out, which they would have to do for the Treasury curve to provide an exactly correct set of discount rates for default-free public pension obligations. Due to these risks priced into the Treasury curve, even default-free public pension obligations are not equivalent to Treasuries.

Table III presents our main estimates of aggregate state pension fund liabilities under the taxable muni and the Treasury discounting respectively. The key results are that total liabilities are $\$ 3.21$ trillion and $\$ 5.20$ trillion under the two measures.

Looking first at the taxable muni measure, the re-discounting from the flat $8 \%$ state-chosen rates affects short-duration cash flows much more than long-duration cash flows, because the long-end of the taxable muni yield curve is itself close to $8 \%$. As a result, the liability owing to separated workers increases by $12 \%$ ( $\$ 0.72$ trillion under state-chosen rates as shown in Table II to $\$ 0.81$ trillion under taxable muni rates as shown in Table III), while the liability owing to annuitants increases by $20 \%(\$ 1.17$ trillion to $\$ 1.40$ trillion). Even though the active component has the longest duration, the ABO for active workers only rises by $10 \%$ (from $\$ 0.91$ trillion to $\$ 1.00$ trillion), because most of the cash flows are longdated, at points on the yield curve where taxable muni yields are close to $8 \%$. Under this measure, the active component is $31 \%$ of the total liability.

Moving from the state-chosen discount rate of $8 \%$ to the Treasury yield curve affects the active worker liabilities the most and the annuitants the least. The discount rate for the short end of the curve is still decreasing by more than the discount rate for the long end of the curve, but the effect of the longer active-worker duration dominates. The liability owing to annuitants is $\$ 1.65$ trillion (41\% higher than 
under the state-chosen rates). The liability owing to separated work6rs is $\$ 1.46$ trillion (103\% higher), and the liability owing to active workers is $\$ 2.08$ trillion (129\% higher).

It is interesting to note that liabilities net of the $\$ 1.94$ trillion in total assets, are $\$ 1.27$ trillion and $\$ 3.26$ trillion under the taxable muni and Treasury discounting measures respectively. For comparison, total state non-pension debt was \$0.94 trillion and total state annual revenues were \$1.99 trillion in 2007. However, just as the funding of the liabilities is irrelevant to their value, the value of liabilities does not determine whether they are adequately funded.

Liabilities calculated using discount rates that are marked to market will vary with market conditions. As mentioned above, one caveat to this entire analysis is that early 2009 may have been an unusual time for bond markets. Indeed, the highest rated municipal bonds were trading at a higher yield than Treasuries despite the tax deductibility of interest on municipal debt. To the extent that the change in the muni spread represents a temporary aversion by investors to all but the safest and most liquid debt securities, one might view the muni rates as "abnormally" high and the Treasury rates as "abnormally" low due to a large liquidity premium. In that case, under more "normal" market conditions, our Treasury measure should be smaller, but our taxable muni measure should be larger. To the extent that the increase in muni yields relative to Treasury yields reflects increased state default probabilities, today's marked-tomarket liability measures reflect market expectations.

For readers interested in seeing the present value of liabilities state-by-state, Table IV lists liabilities under each measure, as well as pension assets, debt, revenue, credit rating, and GDP at the state level.

\section{Duration of Pension Liabilities}

The analysis performed in the previous section also yields, as a byproduct, the sensitivity of the states' liabilities to the rate employed to discount them. The liabilities we calculated in the previous section are higher than the liabilities states reported in their CAFRs. This is because the discount rates we employ, which more accurately reflect the risks of the plans' future obligations from a taxpayer perspective, are lower than those employed by the states. While we are primarily interested in the magnitudes of the states' liabilities, the methodology we develop to value these liabilities can also be used to calculate their duration, and analyzing the duration of the liabilities provides additional intuition as to why the liabilities we calculate differ so dramatically from the states' reported liabilities.

Figure 5 depicts the duration, as a function of the discount rate, of the states' aggregate ABO liability, as well as the durations of the liabilities posed individually by the active, retired and separated 
workers. ${ }^{21}$ The liabilities represented by active and separated workers are quite sensitive to the employed discount rates. These plan participants are relatively young, and consequently expect to receive benefit payments far into the future. Conversely, the liability represented by retired workers is relatively insensitive to the employed discount rate, because the payments they expect to receive are concentrated in the near future. The duration of the aggregate liability is the value-weighted average of the liabilities of the employed, retired and separated workers.

The fact that the durations decrease with the discount rates - i.e., the downward sloping duration profiles observed in Figure 5 - simply reflects the convexity of the liabilities. For any given discount rate, the liabilities' duration is a weighted average of the times until the payments come due, where the weights are the fractions the payments represent of the total liability. As discount rates fall, the fraction of the total liability represented by long dated payments rises, increasing the liability's duration. Note that the duration of the total liability slopes down more than any of the individual components, because as the rate goes up more weight goes on the active and separated workers, whose benefits have longer duration.

Because we are interested in relatively large (non-infinitesimal) changes in the discount rate, and the duration is itself sensitive to the discount rate, there is not a single discount rate at which it is appropriate to measure the duration. We can, however, consider the effective average duration over the relevant discount rate range. That is, we can calculate a single "duration" that corresponds to the average elasticity of the liabilities with respect to discount rates $(-\Delta \ln L / \Delta r)$ over the discount rate range encompassing the states' stated discount rates and the approximate discount rates we use. Over the range $6 \%$ to $8 \%$, the effective average duration is almost $141 / 2$ years, while over the range $4 \%$ to $8 \%$ it is over $15 \frac{1}{2}$ years.

This effective average duration over the range of discount rates we consider, roughly 15 years, is similar to the durations typically assumed for public pension liabilities (Barclays Global Investors (2004), Waring (2004a, 2004b)). However, our analysis shows that there is a great deal of convexity in the promised pension payments, as well as large differences in duration between liabilities posed by active, separated and retired workers.

\section{State Pension Liabilities Under Broader Measures}

Since our model of pension payments delivers a payment stream under each liability measure, we can calculate the present value of benefits under all four of the actuarial methods: ABO, PBO, EAN, and PVB. The first two columns of Table V show the payment streams under all of these measures discounted under our two main yield curves: the taxable muni yield curve and the Treasury yield curve. Recall that

\footnotetext{
${ }^{21}$ For simplicity our duration analysis focuses on parallel shifts to a flat yield curve. This simple analysis is sufficient to generate all the relevant intuition.
} 
the liabilities of the annuitants and separated employees not receiving benefits are not sensitive to the actuarial method.

The first two columns of the first row repeat our headline numbers from Table III. These are total liabilities under the taxable muni and Treasury discount rates: \$3.21 trillion and \$5.20 trillion respectively. The second row shows that the PBO calculated using the same discount rates is $4 \%$ higher under the taxable muni measure than the $\mathrm{ABO}$, and $8 \%$ higher under the Treasury measure. The third row shows the EAN liability. The EAN liability is $6 \%$ higher than the ABO under the taxable muni measure and $11 \%$ higher under the Treasury measure. Note that in dollar terms, the increase in the active participant liability is the same as the increase in the total liability, as the accrual methodology only differs on this component. Given our cash flow estimates, these increases represent upper bounds on the extent of the differences between the broader liability measures and the ABO, since the part of the broader measures above and beyond the $\mathrm{ABO}$ is more easily defaultable than the $\mathrm{ABO}$ and should be discounted at a higher rate than the ABO.

The fourth row shows the PVB. Moving from the ABO to the PVB under taxable muni discounting increases active and total worker liabilities by $\$ 0.6$ trillion, which is $64 \%$ of active ABO liabilities and $20 \%$ of total ABO liabilities. Since most states have at least some freedom to change future benefit accruals for currently employed workers, the discount rates we employ in these first two columns probably overstate the PVB. However, Brown and Wilcox (2009) show that eight state constitutions, including those of major pension sponsors Illinois and New York, say that pensions may not be "diminished or impaired", a clause which presumably protects far more than the ABO by limiting the extent to which ongoing pension accruals can be slowed or stopped. In any case, this exercise does give a sense of the maximum amount that moving from the ABO to the PVB could increase the measure under taxable muni discounting.

As discussed previously, discounting the state PBO at the taxable muni rate bears some resemblance to what FASB requires of firms. This calculation yields a value of $\$ 3.34$ trillion. Under FASB rules, firms must use a high-grade corporate bond rate to discount and recognize the Projected Benefit Obligation (PBO). The corporate bond rate reflects the risk that highly rated corporations will default on their debt. The taxable muni rate reflects the risk that a given state will default. ${ }^{22}$

What if the evolution of pension liabilities is correlated with the market over long horizons? For retired and separated workers, as well as for the entire ABO, this correlation is not relevant. However, it is relevant for broader accrual measures. A correlation between real wages and the market can generate

\footnotetext{
${ }^{22}$ A procedure that would mimic the FASB procedure even more closely would be to discount all state PBOs at an AA taxable muni rate.
} 
positive covariance between pension liabilities and the market through variation in salary growth, a point made by Black (1989) and others.

This issue has been analyzed in a general context with closed form solutions by Sundaresan and Zapatero (1997). Benzoni et al (2007) argue that while the correlation between earnings growth and stock returns is negligible on a short horizon, the correlation is higher on a longer horizon. Lucas and Zeldes (2006) discuss these effects in the context of corporate pension plans with a model in which the value of human capital and the value of the stock market have positive covariance. In data simulated from their model of corporate outcomes, the one-year correlation between earnings growth and stock returns is zero, the three-year correlation is 0.11 , and the five-year correlation is 0.22 .

The extent to which the correlation between earnings growth and stock returns affects the discount rate depends on the volatility of wage growth and market returns, as well as their correlation. The loading of liabilities on the market is $\beta_{L}=\sigma_{L, M} / \sigma_{M}^{2}=\rho_{L, M} \sigma_{L} \sigma_{M} / \sigma_{M}^{2}$, where $\sigma_{L}$ is the volatility (annualized standard deviation) of liabilities, $\sigma_{M}$ is the volatility of the market portfolio, $\sigma_{L, M}$ is the covariance between the two, and $\rho_{L, M}$ is the correlation coefficient between the two. The discount rate would have to be adjusted upwards by $\beta$ times the market risk premium. The volatility of liabilities $\left(\sigma_{L}\right)$ relevant for this equation is the volatility of accrued pension liabilities as the future unfolds.

To the extent possible, we investigate the short- and long-horizon covariance between the market and public pension liabilities. First, we examine the annual standard deviation of the actuarial liabilities for some samples of state pension funds for which we have a balanced panel of data over a medium horizon. We consider one sample of 62 plans for which we have data for 11 years (1997-2007) and another of 27 plans for which we have data for 15 years (1993-2007). The average standard deviation of annual liability growth in these samples is $4.0 \%$ and $4.7 \%$ respectively, while the standard deviation of total liability growth is $1.6 \%$ and $1.4 \%$ respectively. ${ }^{23}$ Most of these liabilities are on an EAN basis.

Second, we make use of government salary data over a 57 year horizon and consider the fact that late-career salaries enter the benefit formula. We use the current population survey (CPS) of the US Census for salary data from 1962-2008. Internet Appendix Table IV shows the raw data. We use these data to calculate the annual growth in full-time government employee average wages during the period 1963-2008. We deflate wage growth by the CPI from the Bureau of Labor Statistics (BLS) website. Figure 6 shows the experience of government salaries versus market returns over the entire sample period.

\footnotetext{
${ }^{23}$ If there is positive serial correlation in liabilities, then long-horizon volatilities would be larger than these oneyear volatilities. If there is negative serial correlation in liabilities, then long-horizon volatilities would be smaller than these one-year volatilities.
} 
Government worker wages appear to grow in a relatively steady fashion and slightly faster than inflation, while the market is substantially more volatile and has a higher average return. ${ }^{24}$

To estimate an accurate relation between government wage growth and the stock market requires more years of data than are available. It does seem, however, that the covariance of government worker wages with the stock market should be smaller than the covariance of corporate worker wages with the stock market. States have rights to tax, and government employment terms are less driven by market forces than corporate terms of employment.

In order to be conservative in discounting the broader liability measures, one might consider assuming that liabilities for active workers have a volatility of 0.05 (based on the EAN balanced panel discussed above) and a correlation with the stock market of 0.25 (the 5-year horizon number from Lucas and Zeldes (2006)). Assuming a 6.5\% risk premium, this would raise the implied discount rate by $6.5 \% * 0.05 * 0.25 / 0.16=51$ basis points. ${ }^{25}$ Our evidence suggests that liabilities are neither this volatile nor this correlated with the market, and there are a number of studies suggesting the risk premium is lower than 6.5\% (Graham and Harvey (2005), Fama and French (2002)). However, we pick this set of assumptions to be conservative in measuring EAN liabilities. If we make the risk premium $3.5 \%-4.5 \%$, the discount rate would only rise by $31 \mathrm{bp}$ under this correction. ${ }^{26}$

The final two columns of Table $\mathrm{V}$ show the effects of adding the $51 \mathrm{bp}$ wage risk in cases where such an addition may be applicable. The third column presents measures assuming that salary risk raises the appropriate discount rate by $51 \mathrm{bp}$ above the taxable muni rate. However, this salary risk only affects the PBO, EAN, and PVB measures, and of course only affects active participants. Therefore, the figures for annuitants and separated workers are identical to those in the first column, as is the entire ABO.

Adding wage risk in this fashion has a moderately small effect on the results. The PBO and EAN for active workers decline by approximately $10 \%$. The percentage impact of wage risk on total liabilities is only $-3 \%$ for the PBO, $-3 \%$ for the EAN, and $-4 \%$ for the PVB under taxable muni discounting, and slightly larger under Treasury discounting (decreases of 5\%-8\%). The effect is substantially muted by the fact that active liabilities only comprise about one-third of the total. So wage risk in this context seems not quantitatively important unless the correlation between the stock market and government wages is substantially higher than 0.25 , or liabilities are much more volatile over the long run, or the market risk premium is substantially higher than $6.5 \%$.

\footnotetext{
${ }^{24} \mathrm{We}$ also ran regressions of government wage growth on the stock market at one, three, and five year horizons. We found betas that were slightly negative with standard errors of $0.02,0.05$, and 0.07 respectively. None of these coefficients were statistically significant.

${ }^{25} \mathrm{We}$ are implicitly assuming that the salary risk is not correlated with the default risk. If defaults are more likely when wages are low, the correction would be less than $51 \mathrm{bp}$.

${ }^{26}$ To the extent that the PVB is more volatile and correlated with the stock market than the EAN, we would want to use larger salary risk corrections for the PVB.
} 
It is interesting to note, however, that discounting the active-worker component of the PBO at a taxable muni rate with wage risk brings the total PBO to $\$ 3.25$ trillion. This PBO measure is only slightly higher than the $\mathrm{ABO}$ at a taxable muni rate that does not reflect wage risk ( $\$ 3.21$ trillion). This is because the salary risk offsets some of the increase in the active-worker liability when one moves to the broader measure, and because the active-worker liability is only one component of the total liability. Similarly, the PBO discounted at the risk-free rate plus wage-risk is $\$ 5.32$ trillion, only about $2 \%$ larger than the $\$ 5.20$ trillion $\mathrm{ABO}$ discounted at the risk-free rate. Thus, moving from the ABO without wage risk to the PBO with wage risk has a small effect. There is a similarly small effect of moving from the ABO without wage risk to the EAN with wage risk.

\section{Conclusion}

In this paper we have measured state pension liabilities under a variety of different accrual methods and discount rates. Our main estimates focus on two primary measures of already-promised pension benefits. The first measure uses a discount rate based on municipal bond yields, corrected for the tax preference enjoyed by municipal bond coupons. The second measure uses a Treasury yield curve.

We find the pension promises already made to state workers are worth at least $\$ 3.21$ trillion as far as taxpayers are concerned, under the assumption that the state can default on these promises to the same extent that it can default on its general obligation debt. This is a conservative estimate because most state constitutions suggest that pension promises are higher in priority than general obligation debt. Also, while a federal bailout of states might affect the distribution of the tax burden across taxpayers in different states, taxpayers would ultimately bear the cost of the bailout. So a federal bailout would not reduce this measure from a taxpayer perspective. Under the Treasury discounting measure, which does not credit states for the ability to default but has the drawback of including risks priced in Treasuries that may not be relevant for public pensions, state pension promises are worth a substantially larger $\$ 5.20$ trillion.

These numbers are clearly higher than those reported by the states themselves in their annual report. The first order difference between our calculations and the states' calculations is the discount rate. The discount rate used by most states is around $8 \%$ at all horizons. Especially for near-term cash flows, this discount rate is far too high. At long horizons it would only be appropriate if one wanted to give states substantial credit for their ability to default on these promises. This does not seem an appropriate basis for financial reporting of public financial liabilities if the goal is to inform taxpayers.

In our main measures we have taken great care to include only $\mathrm{ABO}$ liabilities, which are narrowly defined and delay recognition of a large share of liabilities until later in the employee's life. The covariance between government salaries and pricing factors is also irrelevant for the ABO. However, we find that the broader PBO and EAN measures are not substantially larger. The EAN for active workers is 
only about $\$ 0.2$ trillion larger than the $\mathrm{ABO}$ for active workers using taxable muni rates and $\$ 0.6$ trillion using Treasury rates.

Even these relatively small potential differences between the $\mathrm{ABO}$ and the broader measures are further mitigated by two factors. First, governments are much more likely to default on payments above and beyond the $\mathrm{ABO}$ than they are to default on the $\mathrm{ABO}$ itself. The cash flows above and beyond those associated with the $\mathrm{ABO}$ should therefore be discounted at a higher rate to reflect that greater default risk. Second, the cash flows that are not recognized in the ABO vary with wage growth, which may be correlated with priced risk factors. Our coarse method of capturing salary risk reduces the difference between the EAN and the ABO to \$0.1-\$0.3 trillion. ${ }^{27}$

For comparison to our liability measures, we note that assets in state pension funds were worth approximately $\$ 1.94$ trillion as of the end of 2008. Also for comparison, total state non-pension debt was $\$ 0.94$ trillion and total state annual revenues were $\$ 1.99$ trillion in 2007 . However, just as the funding of the liabilities is irrelevant to their value, the value of liabilities does not determine whether they are funded in an adequate manner.

This raises several important questions for future research. First, what level of assets should be seen as adequate to fully fund the liabilities we measure? To answer this question requires specifying an objective function for the state and its pension managers. Second, how should dedicated pension assets be invested? If households form their own financial portfolios taking government pension policy into account, then how the government invests pension assets does not matter. However, if some households fail to fully undo the government's investment strategy, then investing in risky assets raises both the mean and variance of future generations' after tax wealth, with indeterminate consequences for taxpayer welfare. A large literature has argued that investing public assets in risky securities may allow future generations to benefit from improved inter-generational risk sharing. But if future taxation to meet pension promises has nonlinear distortionary costs, then investing public pensions in risky assets with high expected returns and high volatility may impose a large expected cost of distortionary taxation on future generations, as shown by Lucas and Zeldes (2009). The consideration of this burden in the context of overlapping generations is an important area for future research.

\footnotetext{
${ }^{27}$ Naturally the difference between the PVB and the ABO is more substantial holding the discount rate constant. However, the cautions about holding the discount rate constant between the $\mathrm{ABO}$ and EAN (due to higher default risk and salary risk) are even more relevant for moving between the ABO and PVB.
} 


\section{References}

Bader, Lawrence N. and Jeremy Gold, 2004, “The Case Against Stock in Public Pension Funds," Pension Research Council Working Paper.

Barclays Global Investors, 2004, “The Retirement Benefits Crisis: A Survival Guide,” Barclays Global Investors Investment Insights 7(5).

Barro, Robert, 1976, "Rational Expectations and the Role of Monetary Policy," Journal of Monetary Economics 2, 1-32.

Benninga, Simon, and Aris Protopapadakis, 1985, "Real and Nominal Interest Rates under Uncertainty: The Fisher Problem and the Term Structure," Journal of Political Economy 91, 856-67.

Benzoni, L., P. Collin Dufresne, and R. Goldstein, 2007, "Portfolio Choice over the Life-cycle when the Stock and Labor Markets are Cointegrated," Journal of Finance 62, 2123-2167.

Bergstresser, Daniel, Mihir A. Desai, and Joshua Rauh, 2006, "Earnings Manipulation, Pension Assumptions, and Managerial Investment Decisions," Quarterly Journal of Economics 121(1), 157-195.

Black, Fischer, 1989, “Should You Use Stocks to Hedge Your Pension Liability?” Financial Analysts Journal 45(1), 10-12.

Blocker, Alexander W., Laurence J. Kotlikoff and Stephen A. Ross, 2008, "The True Cost of Social Security,” NBER Working Paper W14427, http://www.nber.org/papers/w14427.

Bodie, Zvi, 1990, “The ABO, the PBO, and Pension Investment Policy,” Financial Analysts Journal 46, 27-34.

Brown, Jeffrey and David Wilcox, 2009, "Discounting State and Local Pension Liabilties," American Economic Review 99(2), 538-542.

Bulow, Jeremy I., 1982, “What Are Corporate Pension Liabilities?" Quarterly Journal of Economics 97(3), 435-452.

Buraschi, Andrea and Alexei Jiltsov, 2005, "Inflation risk premia and the expectations hypothesis," Journal of Financial Economics 75, 429-490.

Bureau of Labor Statistics, 2008, "National Compensation Survey: Employee Benefits in State and Local Governments in the United States, September 2007," BLS Summary 08-02, http://www.bls.gov/ncs/ebs/sp/ebsm0007.pdf

Center for Retirement Research, 2006, http://crr.bc.edu/frequently_requested_data/state_and local_pension_data 4.html

Congressional Budget Office, 2005, “The Risk Exposure of the Pension Guaranty Corporation,” A CBO Paper.

Coronado, Julia L., Eric M. Engen, and Brian Knight, 2003, “The Investment Practices and Performance of State and Local Pensions," National Tax Journal 56(3), 579-594. 
Duffie, Darrell and Kenneth J. Singleton, 1997, “An Econometric Model of the Term Structure of Interest-Rate Swap Yields,” Journal of Finance 52(4), 1287-1321.

Fama, Euguene F., and Kenneth R. French, 2002, “The Equity Premium,” Journal of Finance 57(2), 637659.

Fisher, Stanley, 1975, “The Demand for Index Bonds," Journal of Political Economy 83(3), 509-534.

Geanakoplos, John, and Stephen P. Zeldes, 2009a, "The Market Value of Accrued Social Security Benefits," Working Paper, Columbia University Graduate School of Business.

Geanakoplos, John, and Stephen P. Zeldes, 2009b, "Reforming Social Security with Progressive Personal Accounts," in Social Security Policy in a Changing Environment, J. Brown, J. Liebman, and D. Wise (eds), Chicago: University of Chicago Press, 73-128.

Geanakoplos, John, Olivia Mitchell and Stephen P. Zeldes, 1999, "Social Security Money's Worth," in Prospects for Social Security Reform, O. Mitchell and R. Meyers (eds), University of Pennsylvania Press.

Gierz, J. Fred and Leslie E. Papke, 2007, "Public Pension Plans: Myths and Realities for State Budgets," National Tax Journal 60(2), 305-323.

Gold, Jeremy, 2002, "Risk Transfer in Public Pension Plans," Working Paper 2002-18, Wharton Pension Research Council.

Government Accounting Office (GAO), 2007, "State and Local Government Retirement Benefits: Current Status of Benefit Structures, Protections, and Fiscal Outlook for Funding Future Costs," GAO07-1156, www.gao.gov/new.items/d071156.pdf.

Graham, John R. and Campbell R. Harvey, 2005, “The Long-Run Equity Risk Premium,” Duke University Working Paper, http://papers.ssrn.com/sol3/papers.cfm?abstract id=795369.

Ippolito, Richard A. (2002): "Replicating Default Risk in a Defined Benefit Plan," Financial Analysts Journal 58 (6), 31-40.

Krishnamurthy, Arvind, and Annette Vissing-Jorgensen, 2008, “The Aggregate Demand for Treasury Debt," Kellogg School of Management Working Paper.

Lenze, David G., 2009, “Accrual Measures of Pension-Related Compensation and Wealth of State and Local Government Workers," Working Paper, Bureau of Economic Analysis.

Lintner, L., 1965, "The Valuation of Risk Assets and the Selection of Risky Investments in Stock Portfolios and Capital Budgets," Review of Economic Statistics 47, 13-37.

Longstaff, Francis A., 2004, “The Flight-to-Liquidity Premium in U.S. Treasury Bond Prices,” Journal of Business 77(3), 511-526.

Lucas, Deborah and Stephen P. Zeldes, 2006, "Valuing and Hedging Defined Benefit Pension Obligations - the Role of Stocks Revisited," Working Paper, Northwestern University.

Lucas, Deborah and Stephen P. Zeldes, 2009, "How Should Public Plans Invest," American Economic Review Papers and Proceedings, forthcoming. 
Merrill Lynch Research, 2007, "Public Plans Take Center Stage,” Research Note.

Modigliani, Franco and Merton H. Miller, 1958, "The Cost of Capital, Corporation Finance, and the Theory of Investment," American Economic Review 48: 261-297.

Munnell, Alicia, Kelly Haverstick, Steven Sass, and Jean-Pierre Aubry, 2008a, "The Miracle of Pension Funding by State and Local Pension Plans," Center for Retirement Research, SLP \#5.

Munnell, Alicia, Jean-Pierre Aubry, and Dan Muldoon, 2008b, "The Financial Crisis and State/Local Defined Benefit Plans," Center for Retirement Research, Issue in Brief \#8-19.

National Association of State Retirement Administrators, 2003-2007, Public Fund Survey.

National Conference on Public Employee Retirement Systems (NCPERS), 2007, "State Constitutional Protections for Public Sector Retirement Benefits,"

www.ncpers.org/Files/News/03152007RetireBenefitProtections.pdf

Peng, Jun, 2009, State and Local Pension Fund Management, Boca Raton: CRC Press.

Petersen, Mitchell A., 1996, "Allocating Assets and Discounting Cash Flows: Pension Plan Finance," in P. A. Fernandez, J. A. Turner, and R. P. Hinz (eds.), Pensions, Savings and Capital Markets, Washington, D.C.: U.S. Department of Labor.

Pew Charitable Trust, 2007, Promise with a Price: Public Sector Retirement Benefits.

Poterba, James, and Arturo Ramirez Verdugo, 2008, "Portfolio Substitution and the Revenue Cost of Exempting State and Local Government Interest Payments from the Federal Income Tax," MIT Department of Economics Working Paper.

Rauh, Joshua, 2006, "Investment and Financing Constraints: Evidence from the Funding of Corporate Pension Plans," Journal of Finance 61, 33-71.

Rauh, Joshua, 2009, "Risk Shifting versus Risk Management: Investment Policy in Corporate Pension Plans," Review of Financial Studies 22(7), 2687-2734.

Sharpe, W.F., 1964, "Capital Asset Prices: A Theory of Market Equilibrium under Conditions of Risk," Journal of Finance 19, 425-442.

Sundaresan, Suresh and Fernando Zapatero, 1997, "Valuation, Optimal Asset Allocation and Retirement Incentives of Pension Plans," Review of Financial Studies 10(3), 631-660.

Treynor, Jack L., 1961, “Toward a Theory of the Market Value of Risky Assets,” Unpublished Manuscript.

Treynor, Jack L., 1976, “The Principles of Corporate Pension Finance,” Journal of Finance 32, 627-638.

US Census Bureau, Census of Governments, 2007.

Waring, M. Barton, 2004a, "Liability-relative investing," Journal of Portfolio Management 30(4). 
Waring, M. Barton, 2004b, “Liability-relative investing II," Journal of Portfolio Management 31(1).

Winklevoss, Howard E., 1993, Pension Mathematics with Numerical Illustrations, 2nd ed. (Pension Research Council of the Wharton School of the University of Pennsylvania and University of Pennsylvania Press).

Woodford, Michael, 1990, "Public Debt as Private Liquidity," American Economic Review 80, 382-88.

Yang, Tongxuan (Stella) \& Olivia S. Mitchell, 2006, "Public Pension Governance, Funding, and Performance: A Longitudinal Appraisal," in John Evans and John Piggott (eds), Pension Fund Governance: A Global Perspective, Edward Elgar (forthcoming). 


\section{Figure 1: Illustration of Liabilities Under Different Accrual Concepts}

Liabilities by age are shown for hypothetical workers hired at age 20 and retiring at age 65 . Four different accounting methods are illustrated: Accumulated Benefit Obligation (ABO), Projected Benefit Obligation (PBO), Entry Age Normal (EAN), and Projected Value of Benefits (PVB). The figure relies on assumptions about wage growth by age, as well as the age-service distribution of workers, based on CAFRs from the 10 states with the largest pension liabilities (see Internet Appendix Table III for details). It assumes that a 65 year old worker with 45 years of service would earn $\$ 100,000$. It also uses a 3.5\% inflation rate, a $2 \%$ benefit formula, a $3 \%$ fixed cost of living adjustment (COLA), an $8 \%$ discount rate, and death probabilities taken from the RP2000 combined mortality table.

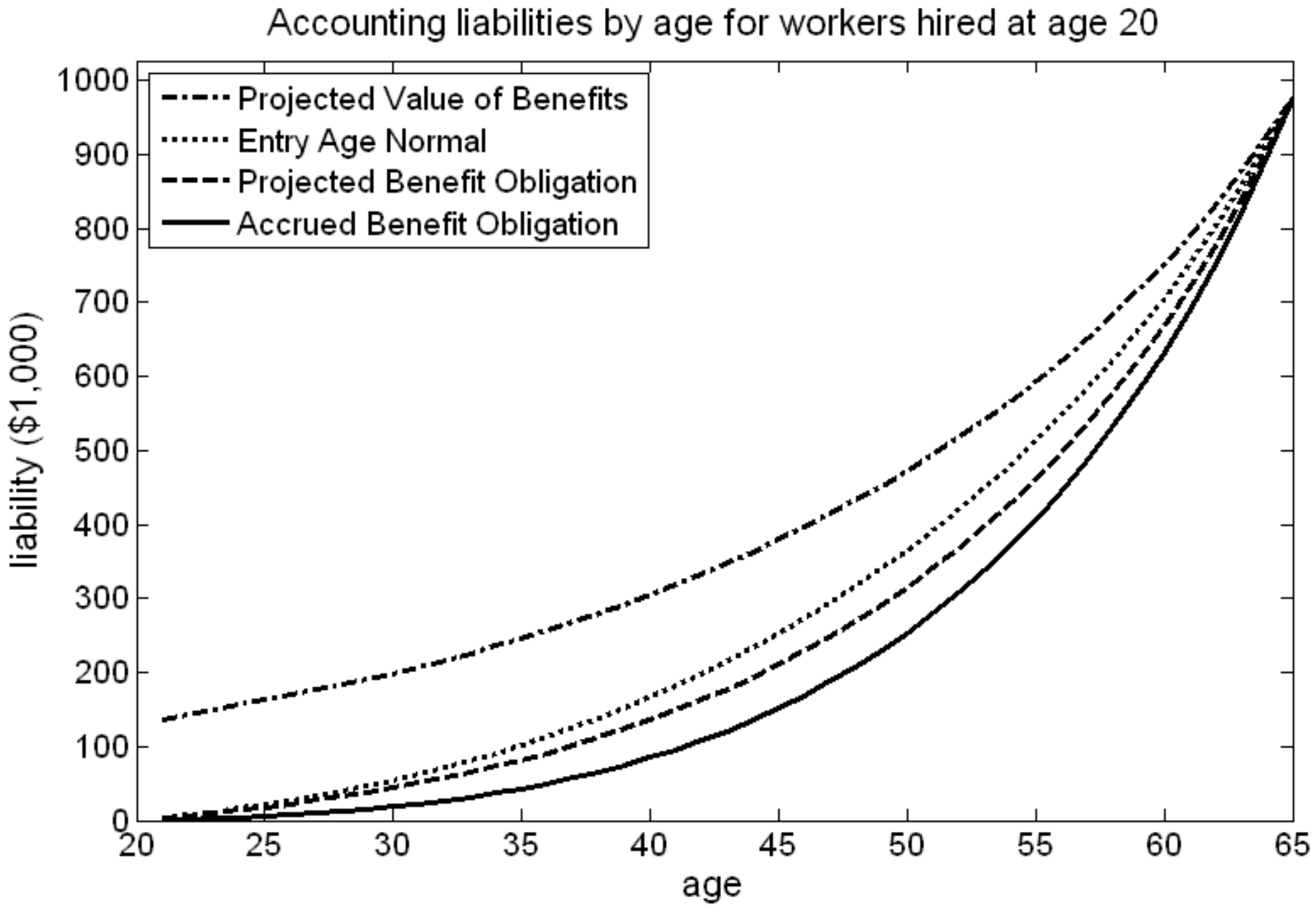


Figure 2: Projected Aggregate Cash Flows for Public Pension Promises

This figure shows projected aggregate cash flows by state governments due to public pension promises, as would be recognized under different accrual methods. Cash flow projections for each state plan are made so that the state plan's reported liability equals the discounted value of these cash flows under the state's chosen accrual method and reported discount rate. The distribution of cash flows over years relies on assumptions about wage growth by age, as well as the ageservice distribution of workers, based on CAFRs from the 10 states with the largest pension liabilities (see Internet Appendix Table III for details). Benefit formulas, cost of living adjustments (COLAs) and inflation assumptions are derived on a plan-by-plan basis from the CAFRs and the Center for Retirement Research (2006).

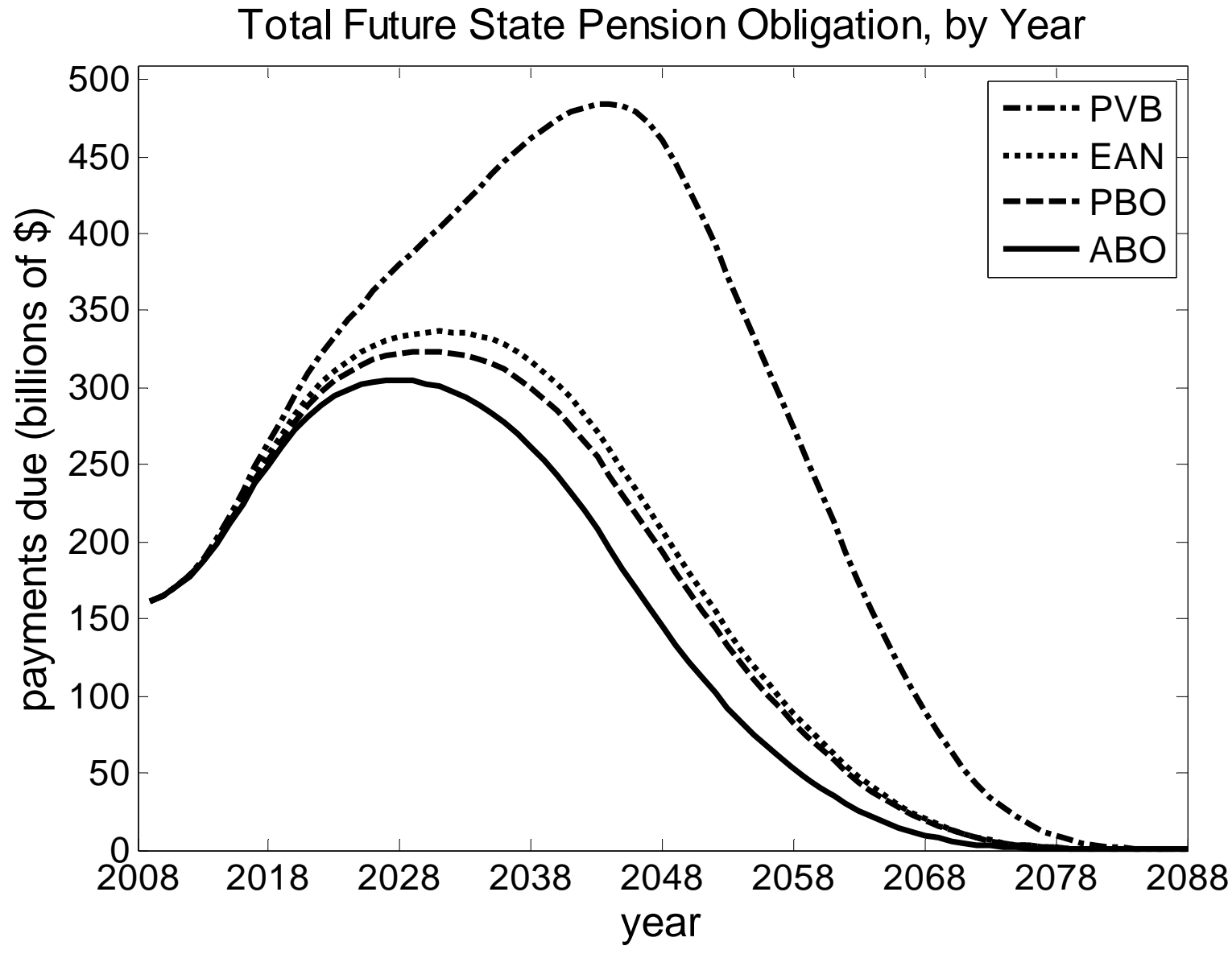


Figure 3: Projected Aggregate Cash Flows for Active, Annuitants, and Separated Participants This figure decomposes the projected aggregate cash flows shown in Figure 2 into cash flows to currently active workers, current annuitants, and people who are no longer working for the state but also not yet retired. Cash flow projections for each state plan are made so that the state plan's reported liability equals the discounted value of these cash flows under the state's chosen accrual method and reported discount rate.
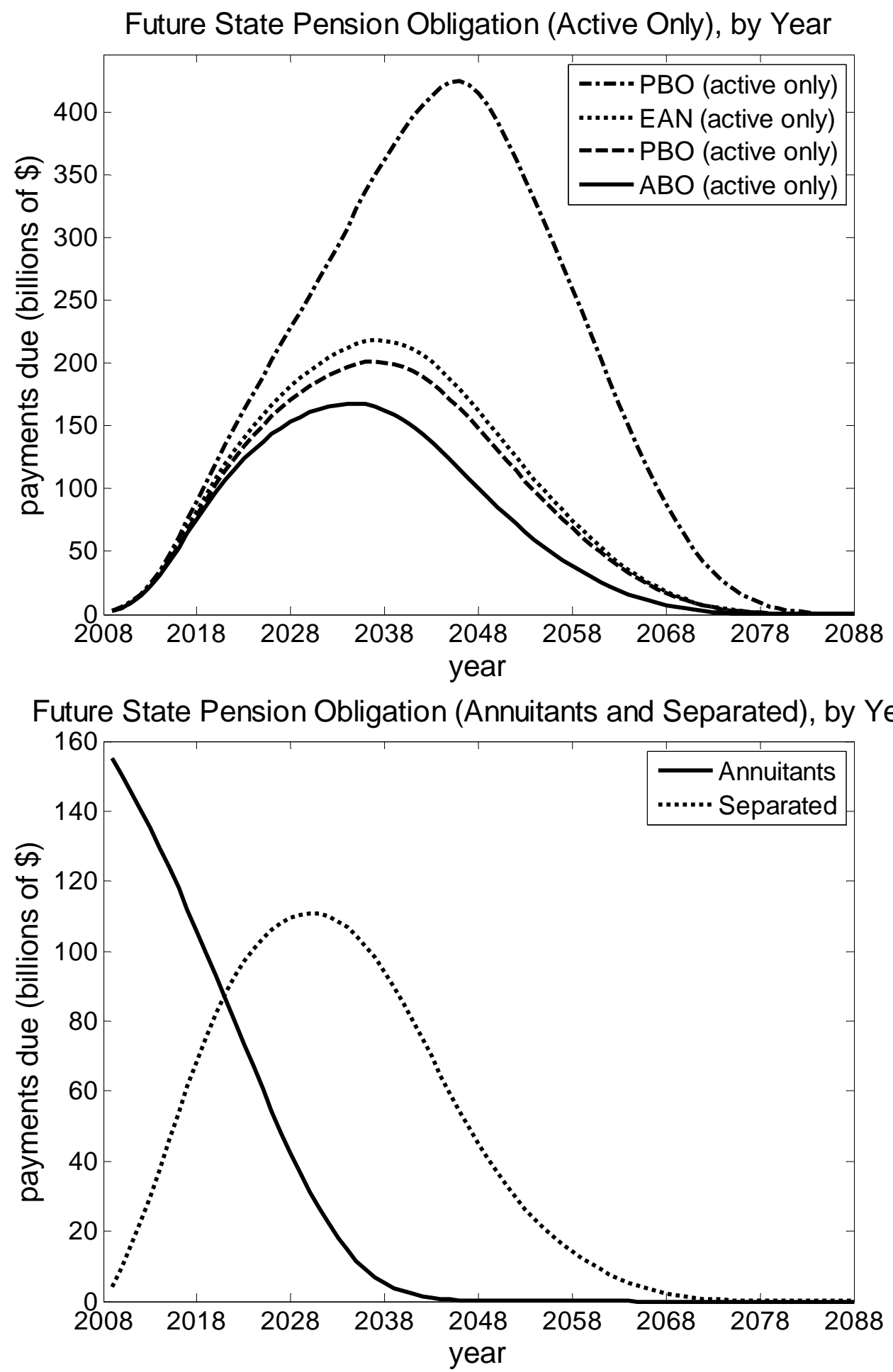


\section{Figure 4: Zero-Coupon Yield Curves for Treasuries and Municipal Bonds}

This graph shows zero-coupon yield curves for Treasuries, as well as municipal bonds of various ratings, as of January 30, 2009. Yields on coupon bonds were collected from Bloomberg for AAA, AA+, AA-, A+, and A- rated state municipal bonds. The zero-coupon yields were calculated from strip prices, which we obtained by constructing long-short portfolios of the coupon bonds. We interpolate between AA+ and AA- to obtain an AA curve, and between A+ and A- to obtain an A curve.

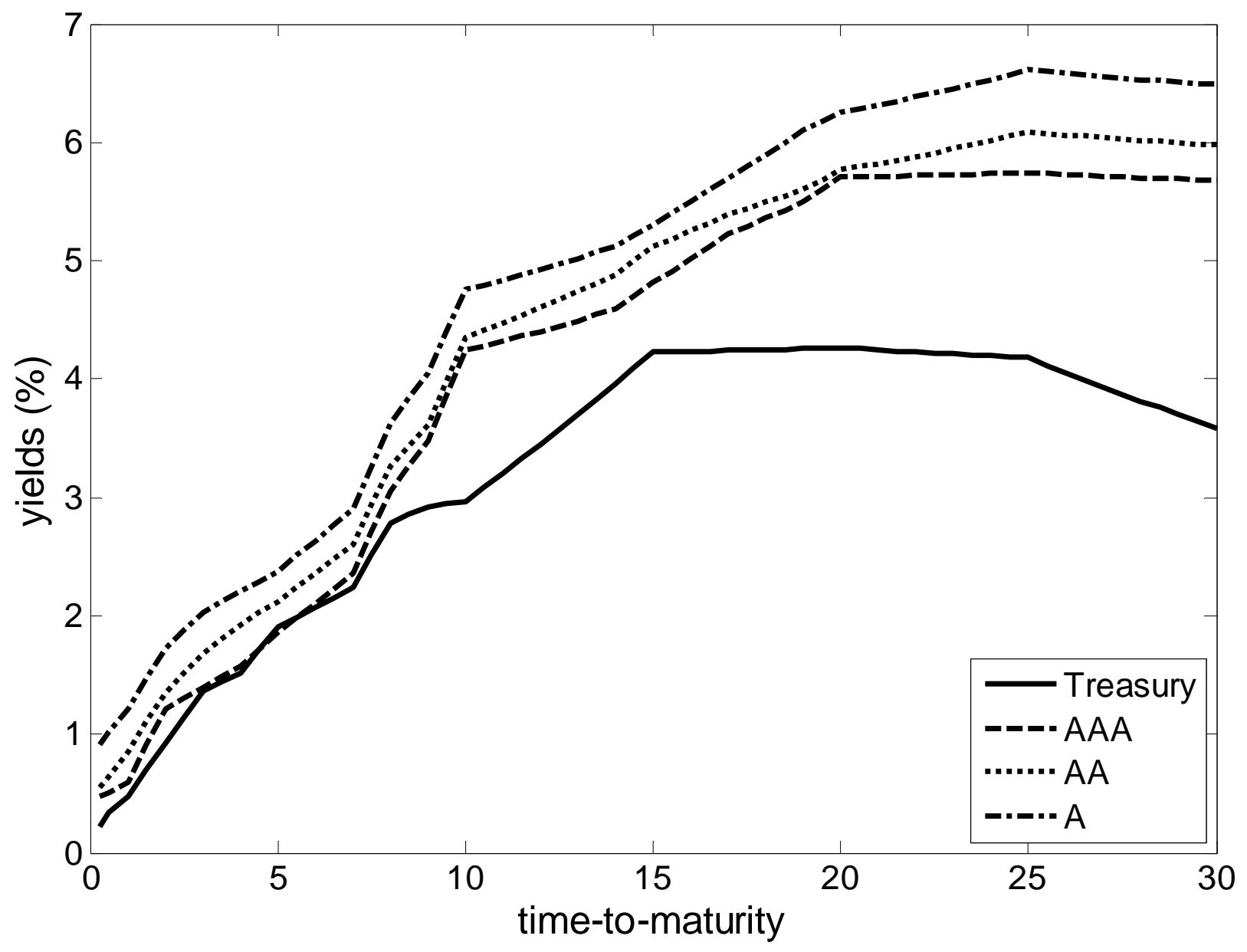




\section{Figure 5: Implied Durations of Public Pension Liabilities}

This figure shows the duration of the states' aggregate ABO liability (solid line), as a function of the employed discount rate. It also shows the durations of the individual components of the aggregate liability, i.e., the duration of the liabilities posed individually by the active, separated and retired workers (dashed, dotted and dash-dotted lines, respectively).

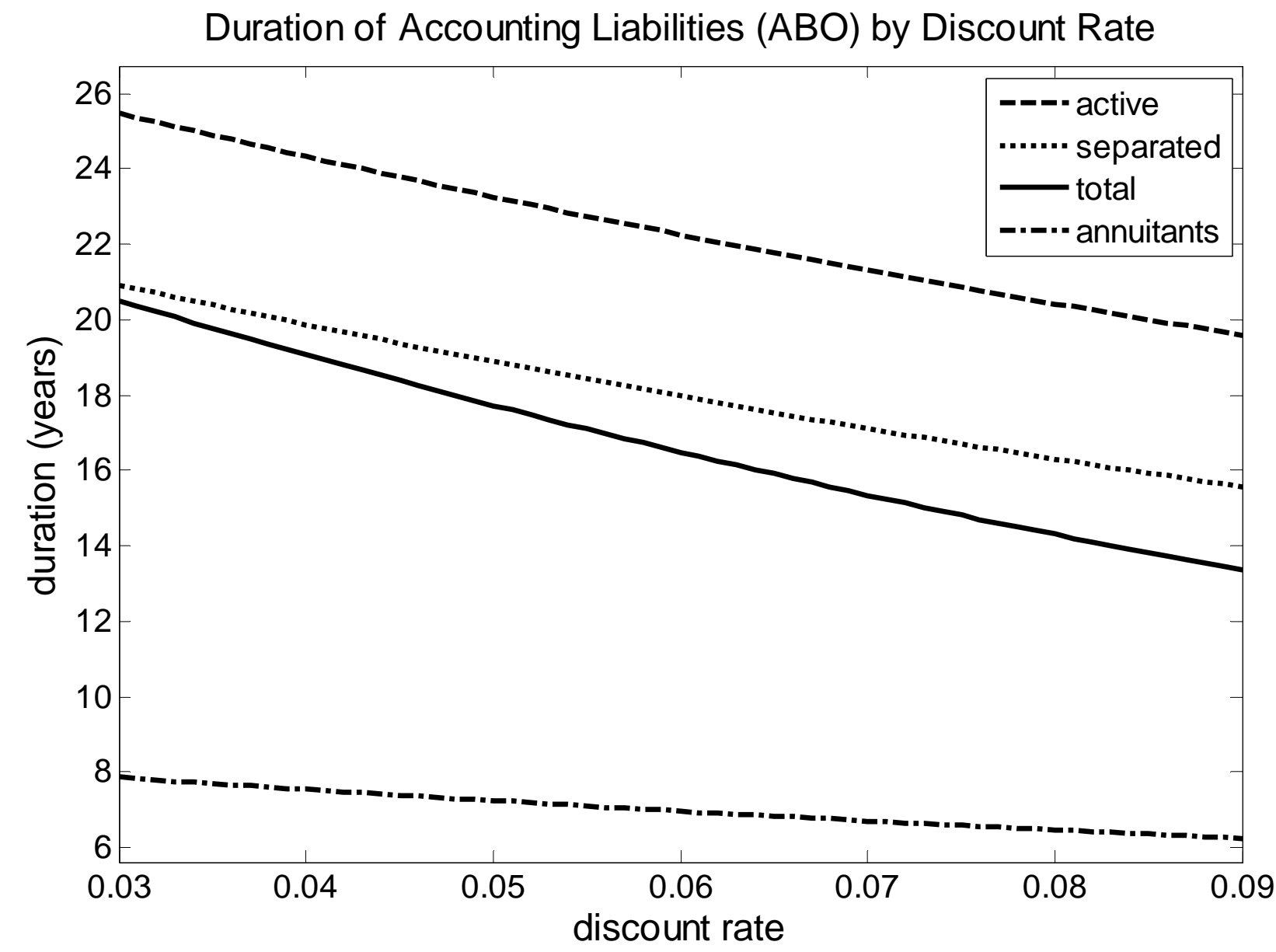




\section{Figure 6: Government Salary Growth and Market Returns}

This figure shows returns on a wage index of government workers and returns on the market portfolio. The wage index comes from the Current Population Survey (CPS) of the US Census for all government workers between 1962 and 2006. The wage index is deflated by Consumer Price Inflation (CPI) growth, as reported on the Bureau of Labor Statistics (BLS) website. The return on the US stock market is adjusted by the risk-free rate, and is extracted from the Kenneth R. French data.

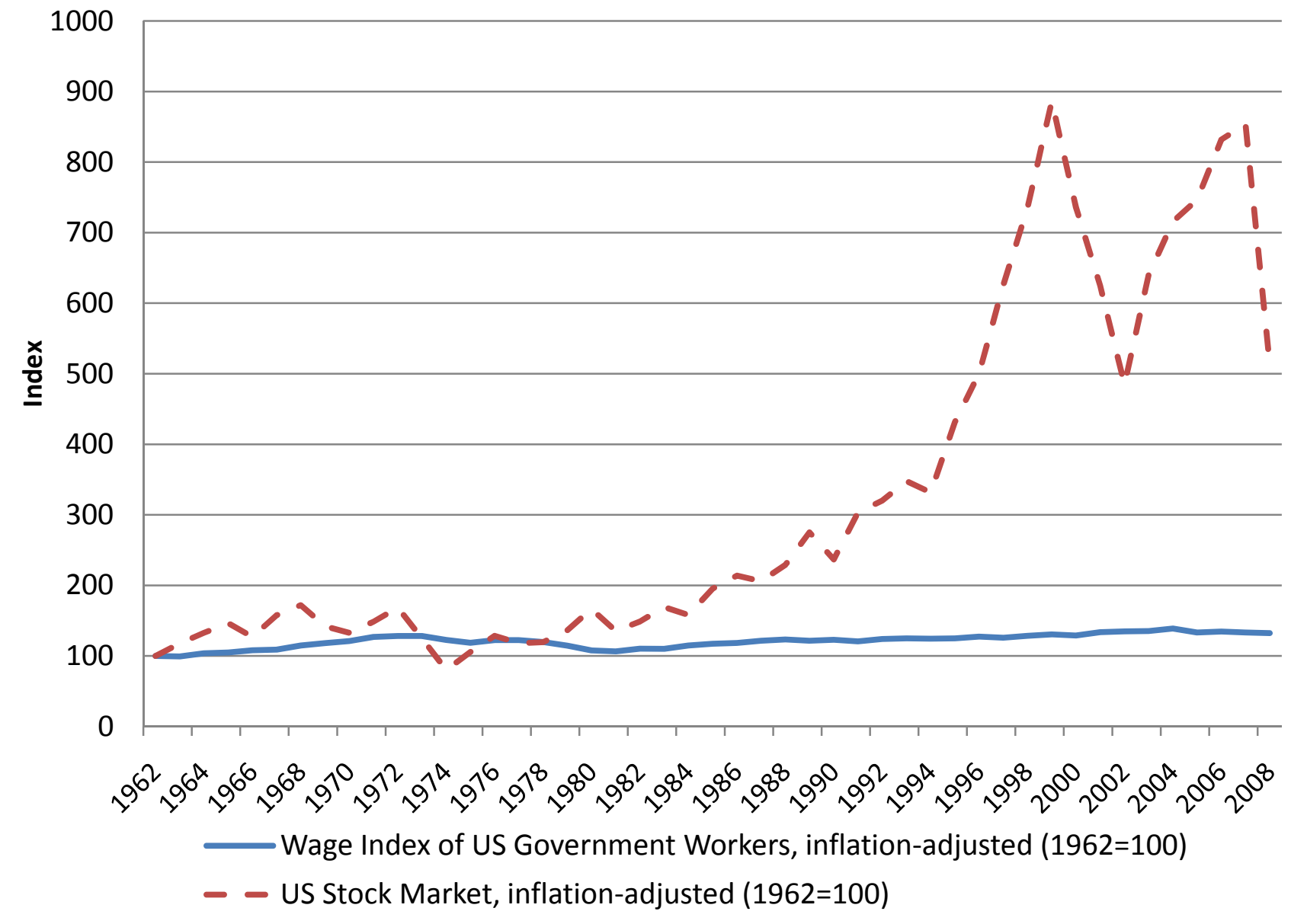




\section{Table I: Summary of Plan Characteristics}

This table shows plan characteristics as collected for as many of our 116 sample plans as possible. The data were taken from the CAFRs and from Center for Retirement Research (2006). Where data were unavailable, these items were ultimately filled in with sample means, but the table shows the data before that step. For 28 plans, benefit factors were given as a range, for which we picked the midpoint. For Cost of Living Adjustment (COLAs), the summary statistics shown are the COLAs that we estimate are built into the states' nominal cash flow projections. The easiest case was if the COLA was fixed, in which case the COLA is just the fixed number given. If the COLAs were a CPI with a cap or Partial CPI, the given formula was applied to the state's inflation assumption. If the COLA was ad hoc, excess earning, or other, we assumed the projected COLA equaled the state's inflation assumption.

\begin{tabular}{|c|c|c|c|c|c|c|c|c|c|}
\hline & \multicolumn{2}{|c|}{ Benefit Factor } & \multicolumn{2}{|c|}{ Inflation } & \multicolumn{2}{|c|}{ Discount Rate } & \multicolumn{3}{|c|}{$\begin{array}{c}\text { Cost of Living } \\
\text { Adjustment (COLA) } \\
\end{array}$} \\
\hline Mean & $1.97 \%$ & & $3.54 \%$ & & $7.97 \%$ & & & $3.13 \%$ & \\
\hline Median & $2.00 \%$ & & $3.50 \%$ & & $8.00 \%$ & & & $3.00 \%$ & \\
\hline Mode & $2.00 \%$ & & $3.00 \%$ & & $8.00 \%$ & & & $3.00 \%$ & \\
\hline Standard deviation & $0.36 \%$ & & $5.71 \%$ & & $0.33 \%$ & & & $0.77 \%$ & \\
\hline Count & 94 & & 91 & & 102 & & & 94 & \\
\hline Detail & $<2.00 \%$ & 40 & $<3.00 \%$ & 2 & $7.00 \%$ & 2 & Fixed & & 19 \\
\hline & $2.00 \%$ & 20 & $3.00 \%$ & 29 & $7.25 \%$ & 5 & CPI wit & Cap & 26 \\
\hline & $>2.00 \%$ & 34 & $3.25 \%$ & 5 & $7.50 \%$ & 13 & Ad hoc & & 20 \\
\hline & & 94 & $3.50 \%$ & 24 & $7.75 \%$ & 7 & Excess & arning & 5 \\
\hline & & & $3.75 \%$ & 7 & $7.80 \%$ & 1 & Partial & & 11 \\
\hline & & & $4.00 \%$ & 12 & $8.00 \%$ & 45 & Other & & 13 \\
\hline & & & $4.50 \%$ & 5 & $8.25 \%$ & 15 & & & 94 \\
\hline & & & $5.00 \%$ & 5 & $8.50 \%$ & 14 & & & \\
\hline & & & Other & 2 & & 102 & & & \\
\hline & & & & 91 & & & & & \\
\hline
\end{tabular}




\section{Table II: State Pension Liabilities Under Stated Discount Rates and Various Actuarial Methods}

The table shows aggregate U.S. state public pension liabilities adjusted to different actuarial methods, using the state-chosen discount rate (on average 8\%). The starting point is the $\$ 2.98$ trillion of liabilities in the top cell, which is the sum of liabilities as reported in the latest financial reports of the 116 plans projected as necessary to 2008 . As the reports use a mix of actuarial methods, the next four rows adjust the liabilities based on different measures of accrued liabilities for active workers. These adjustments only affect active participants, as shown in the remaining rows of numbers. As described in the text, the adjustments are done by modeling the implied stream of payments that is consistent with each state's liabilities and a set of actuarial assumptions based on representative plans.

Figures in trillions of U.S. dollars

Liability

Total (Active + Annuitants + Separated)

As Stated, Unharmonized

Accumulated Benefit Obligation (ABO)

Projected Benefit Obligation (PBO)

Entry Age Normal (EAN)

Projected Value of Benefits (PVB)

Active Participants Only

Accumulated Benefit Obligation (ABO)

Projected Benefit Obligation (PBO)

Entry Age Normal (EAN)

Projected Value of Benefits (PVB)

Annuitants Only

Separated Not Yet

$\$ 0.72$

Receiving Benefits Only 


\section{Table III: Summary of Aggregate State Public Pension Liabilities}

This table presents the two measures of state public pension liabilities, as well as the rates and assumptions used to calculate them. In the top panel, benefits are assumed to have equal priority to state general obligation (GO) bonds. They are discounted at municipal bond rates excluding the tax preference, based on the zero-coupon municipal yield curve as of January 30, 2009. In the bottom panel, Treasury rates are used as an approximation for an appropriate default-free rate, even though Treasury yields likely contain priced inflation and liquidity risks. Under the Treasury discounting procedure, Liabilities are discounted using the zero-coupon Treasury yield curve as of January 30, 2009. These yield curves are shown in Figure 3. In both panels, active worker liabilities are calculated using the Accumulated Benefit Obligation (ABO) accrual methodology.

Taxable Muni Curve Discounting

Risk Assumption: Equal Priority to General Obligation (GO) Bonds

Discount rate: $\frac{r_{m u n i(j)}}{1-\tau_{B}}$, the state-specific municipal bond rate excluding the tax preference

Amount

Annuitants

Separated Not Yet Receiving Benefits

$\$ 1.40$ trillion

Actives (Accumulated Benefit Obligation)

$\$ 0.81$ trillion

Total ABO Liabilities

$\$ 1.00$ trillion

Total ABO Liabilities

Treasury Yield Curve Discounting

Risk Assumption: Default-free

Discount rate: $r_{f}$, the Treasury rate

$\$ 3.21$ trillion

\begin{tabular}{ll} 
& \multicolumn{2}{c}{ Amount } \\
\cline { 2 - 3 } Annuitants & $\$ 1.65$ trillion \\
Separated Not Yet Receiving Benefits & $\$ 1.46$ trillion \\
Actives (Accumulated Benefit Obligation) & $\$ 2.08$ trillion \\
\hline Total ABO Liabilities & $\$ 5.20$ trillion \\
\hline
\end{tabular}


Table IV: State Pension Data for 2008 (\$ billions)

\begin{tabular}{|c|c|c|c|c|c|c|c|c|}
\hline $\begin{array}{l}\text { State Name } \\
\text { (Number of } \\
\text { Plans) }\end{array}$ & $\begin{array}{c}\text { Pension } \\
\text { Liabilities, } \\
\text { Stated }\end{array}$ & $\begin{array}{l}\text { Pension } \\
\text { Liabilities, } \\
\text { Taxable } \\
\text { Muni Rate }\end{array}$ & $\begin{array}{l}\text { Pension } \\
\text { Liabilities, } \\
\text { Treasury } \\
\text { Rate }\end{array}$ & $\begin{array}{c}\text { Pension } \\
\text { Assets }\end{array}$ & $\begin{array}{l}\text { State } \\
\text { Debt } \\
(2007) \\
\end{array}$ & $\begin{array}{c}\text { Revenues } \\
(2007)\end{array}$ & $\begin{array}{l}\text { GDP } \\
(2007)\end{array}$ & $\begin{array}{c}\text { S\&P } \\
\text { General } \\
\text { Obligation } \\
\text { Rating }\end{array}$ \\
\hline Alabama (3) & 41.0 & 45.2 & 79.2 & 22.3 & 7.1 & 27.5 & 165.8 & AA \\
\hline Alaska (2) & 14.5 & 16.0 & 24.6 & 11.7 & 6.6 & 12.5 & 44.5 & $\mathrm{~A}+$ \\
\hline Arizona (3) & 40.6 & 41.7 & 85.5 & 25.0 & 9.5 & 29.9 & 247.0 & NR \\
\hline Arkansas (3) & 20.8 & 22.6 & 38.3 & 8.1 & 4.5 & 18.2 & 95.4 & AA \\
\hline California (3) & 484.2 & 485.4 & 808.4 & 330.0 & 114.7 & 299.9 & 1813.0 & A \\
\hline Colorado (1) & 55.6 & 58.5 & 106.1 & 29.3 & 14.9 & 26.9 & 236.3 & NR \\
\hline Connecticut (3) & 42.8 & 50.1 & 82.1 & 20.4 & 23.8 & 25.5 & 216.3 & AA \\
\hline Delaware (1) & 6.9 & 7.9 & 12.2 & 6.2 & 5.2 & 7.4 & 60.1 & AAA \\
\hline Florida (1) & 124.1 & 136.4 & 214.3 & 97.2 & 36.3 & 95.0 & 734.5 & AAA \\
\hline Georgia (2) & 75.2 & 81.0 & 137.4 & 53.7 & 11.4 & 45.1 & 396.5 & AAA \\
\hline Hawaii (1) & 16.6 & 18.2 & 28.3 & 8.3 & 6.0 & 11.2 & 61.5 & $\mathrm{AA}$ \\
\hline Idaho (1) & 11.9 & 11.4 & 21.0 & 8.1 & 2.8 & 9.1 & 51.1 & NR \\
\hline Illinois (4) & 151.1 & 176.9 & 288.0 & 65.7 & 54.5 & 71.3 & 609.6 & AA \\
\hline Indiana (2) & 36.4 & 38.6 & 62.8 & 15.5 & 19.2 & 32.4 & 246.4 & AAA \\
\hline Iowa (1) & 24.5 & 23.1 & 42.5 & 18.1 & 6.7 & 19.1 & 129.0 & NR \\
\hline Kansas (1) & 20.1 & 19.9 & 36.2 & 10.3 & 5.7 & 15.0 & 117.3 & NR \\
\hline Kentucky (3) & 43.6 & 42.4 & 75.2 & 21.6 & 10.9 & 25.4 & 154.2 & NR \\
\hline Louisiana (2) & 35.7 & 40.3 & 62.6 & 17.7 & 14.3 & 33.3 & 216.1 & $\mathrm{~A}+$ \\
\hline Maine (1) & 13.7 & 14.8 & 24.2 & 8.3 & 5.3 & 9.4 & 48.1 & AA \\
\hline Maryland (1) & 50.2 & 56.1 & 88.7 & 27.8 & 19.0 & 34.8 & 268.7 & AAA \\
\hline Massachusetts (2) & 55.4 & 62.6 & 97.9 & 37.8 & 67.9 & 49.4 & 351.5 & $\mathrm{AA}$ \\
\hline Michigan (4) & 69.9 & 76.1 & 119.6 & 43.4 & 33.7 & 63.1 & 382.0 & AA- \\
\hline Minnesota (4) & 57.9 & 68.8 & 110.5 & 36.2 & 8.9 & 38.7 & 255.0 & AAA \\
\hline Mississippi (3) & 29.3 & 31.7 & 51.9 & 15.1 & 5.9 & 22.4 & 88.5 & $\mathrm{AA}$ \\
\hline Missouri (3) & 51.3 & 58.4 & 89.1 & 27.0 & 18.7 & 32.7 & 229.5 & AAA \\
\hline Montana (2) & 8.6 & 9.9 & 15.5 & 5.9 & 4.6 & 7.1 & 34.3 & $\mathrm{AA}$ \\
\hline Nebraska (2) & 7.9 & 7.8 & 14.1 & 5.4 & 2.2 & 10.0 & 80.1 & NR \\
\hline Nevada (1) & 24.0 & 26.3 & 44.1 & 17.8 & 4.1 & 14.2 & 127.2 & $\mathrm{AA}+$ \\
\hline New Hampshire & 7.8 & 8.9 & 14.3 & 4.4 & 7.7 & 7.2 & 57.3 & AA \\
\hline New Jersey (4) & 123.4 & 138.2 & 206.7 & 60.5 & 51.4 & 65.5 & 465.5 & $\mathrm{AA}$ \\
\hline New Mexico (2) & 26.7 & 29.2 & 45.2 & 16.2 & 7.3 & 16.8 & 76.2 & $\mathrm{AA}+$ \\
\hline New York (3) & 227.0 & 243.7 & 357.8 & 189.8 & 110.1 & 178.9 & 1103.0 & AA \\
\hline North Carolina & 68.7 & 71.0 & 117.2 & 59.1 & 19.2 & 51.8 & 399.4 & AAA \\
\hline North Dakota (2) & 3.6 & 4.0 & 6.8 & 2.9 & 1.8 & 4.8 & 27.7 & AA \\
\hline Ohio (5) & 190.9 & 212.9 & 335.1 & 115.6 & 26.1 & 86.4 & 466.3 & $\mathrm{AA}+$ \\
\hline Oklahoma (4) & 32.3 & 35.1 & 55.0 & 12.0 & 8.7 & 22.3 & 139.3 & $\mathrm{AA}+$ \\
\hline Oregon (1) & 56.6 & 62.3 & 91.4 & 46.1 & 11.3 & 30.6 & 158.2 & $\mathrm{AA}$ \\
\hline Pennsylvania (2) & 104.1 & 123.5 & 193.2 & 70.9 & 37.1 & 83.4 & 531.1 & AA \\
\hline Rhode Island (1) & 12.4 & 14.8 & 27.3 & 6.0 & 8.4 & 8.4 & 46.9 & AA \\
\hline South Carolina & 39.7 & 40.9 & 68.7 & 21.8 & 15.0 & 27.5 & 152.8 & $\mathrm{AA}+$ \\
\hline South Dakota (1) & 7.1 & 7.2 & 13.7 & 6.0 & 3.2 & 4.9 & 33.9 & NR \\
\hline Tennessee (1) & 34.7 & 36.3 & 58.3 & 25.8 & 4.1 & 29.5 & 243.9 & $\mathrm{AA}+$ \\
\hline Texas (4) & 179.0 & 188.2 & 313.7 & 125.3 & 23.9 & 114.7 & 1142.0 & AA \\
\hline Utah (3) & 20.4 & 23.4 & 38.5 & 18.6 & 5.9 & 15.9 & 105.7 & AAA \\
\hline Vermont (3) & 3.8 & 4.3 & 6.8 & 2.4 & 3.1 & 5.4 & 24.5 & $\mathrm{AA}+$ \\
\hline Virginia (1) & 61.6 & 64.7 & 100.0 & 41.3 & 19.7 & 47.2 & 383.0 & AAA \\
\hline Washington (7) & 58.9 & 66.2 & 100.7 & 44.3 & 21.1 & 47.0 & 311.3 & $\mathrm{AA}+$ \\
\hline West Virginia (2) & 12.3 & 13.0 & 19.4 & 6.6 & 5.6 & 11.9 & 57.7 & AA- \\
\hline Wisconsin (1) & 82.9 & 91.0 & 154.6 & 62.2 & 21.5 & 40.2 & 232.3 & $\mathrm{AA}$ \\
\hline Wyoming (4) & 7.0 & 7.7 & 12.4 & 4.8 & 1.2 & 5.8 & 31.5 & $\mathrm{AA}$ \\
\hline TOTAL (116) & $2,975.1$ & $3,214.7$ & $5,196.9$ & $1,936.7$ & 937.8 & $1,992.6$ & 113,649 & \\
\hline
\end{tabular}




\section{Table V: State Public Pension Liabilities Under Various Discount Rates and Accrual Methods}

The table shows aggregate U.S. state public pension liabilities adjusted to different discount rates and accrual methods. The first column discounts the pension payments at taxable muni rates, based on taxable municipal zero-coupon yield curves as of January 30, 2009. The second column discounts the cash flows using the Treasury zero-coupon yield curve as of January 30, 2009. These yield curves are shown in Figure 4 . The third column discounts with the taxable muni rate plus a $51 \mathrm{bp}$ salary risk premium, and the fourth column discounts with the Treasury rate plus a $51 \mathrm{bp}$ salary risk premium. The salary risk premium is only added to the active worker component, and it is also not added to the ABO since the ABO is invariant to future salary growth. As described in the text, the rediscounting is done by modeling the implied stream of payments that is consistent with each state's liabilities and a set of actuarial assumptions based on representative plans.

\section{Figures in trillions of dollars}

Total (Active + Annuitants + Separated)

Accumulated Benefit Obligation (ABO)

Projected Benefit Obligation (PBO)

Entry Age Normal (EAN)

Projected Value of Benefits (PVB)

\section{Active Participants}

Accumulated Benefit Obligation (ABO)

Projected Benefit Obligation (PBO)

Entry Age Normal (EAN)

Projected Value of Benefits (PVB)

Annuitants

Separated Not Yet

Receiving Benefits

\begin{tabular}{|c|c|c|c|}
\hline$\frac{r_{\text {muni }(j)}}{1-\tau_{B}}$ & $r_{\text {Treasury }}$ & $\begin{array}{l}\quad \frac{r_{\operatorname{muni}(j)}}{1-\tau_{B}}+ \\
\text { Wage Risk if } \\
\text { applicable }\end{array}$ & $\begin{array}{c}r_{\text {Treasury }}+ \\
\text { Wage Risk if } \\
\text { applicable }\end{array}$ \\
\hline
\end{tabular}

$\$ 3.21$

$\$ 3.34$

$\$ 3.40$

$\$ 3.86$

$\$ 1.01$

$\$ 1.13$

$\$ 1.20$

$\$ 1.65$

$\$ 1.40$

$\$ 0.81$
$\$ 5.20$

$\$ 5.61$

$\$ 5.78$

$\$ 7.54$

$\$ 2.08$

$\$ 2.49$

$\$ 2.66$

$\$ 4.42$

$\$ 1.65$

$\$ 1.46$
$\$ 3.21$

$\$ 3.25$

$\$ 3.30$

$\$ 3.69$

$\$ 1.01$

$\$ 1.04$

$\$ 1.09$

$\$ 1.48$

$\$ 1.40$

$\$ 0.81$
$\$ 5.20$

$\$ 5.32$

$\$ 5.47$

$\$ 6.95$
$\$ 2.36$

$\$ 3.83$

$\$ 1.65$

$\$ 1.46$ 


\section{Internet Appendix Table I: Assets Held in State Pension Funds, in Trillions of Dollars}

This table shows assets held in the public pension funds of U.S. states, denominated in trillions of dollars. Measurements are shown from two sources: the plan's latest Comprehensive Annual Financial Report (CAFR), and the Pensions and Investments survey of January 2009 reflecting asset allocation as of September 30 , 2008. The table also shows estimates based on these two sources for state pension fund assets as of December 31 , 2008. The estimates are based on the reported asset allocations for each plan from these two sources and asset class returns over the relevant time periods (see Internet Appendix Table II for details).

Latest Comprehensive Annual Financial Reports (CAFR)

June 30, 2008 Reports

December 31, 2007 Reports

June 30, 2007 Reports

Other Dates

Raw Sum of Latest Reports

December 31, 2008 (Estimated)

Pensions and Investments Survey

September 30, 2007, All Plans

September 30, 2008, All Plans

December 31, 2008 (Estimated)

\begin{tabular}{rr} 
Assets & Plans \\
\hline$\$ 1.29$ & 66 \\
$\$ 0.25$ & 16 \\
$\$ 0.56$ & 22 \\
$\$ 0.50$ & 12 \\
& \\
$\$ 2.59$ & 116 \\
$\$ 2.02$ &
\end{tabular}

Assets

$\$ 2.66$

$\$ 2.30$

$\$ 1.94$ 


\section{Internet Appendix Table II: Asset Allocation and Asset Class Returns}

As a proxy for the returns to domestic stock, international stock and real estate we use the returns to Barra/MSCI Investible Indices (USA, World ex-USA and US REIT, respectively). For domestic fixed income, international fixed income, mortgages and "other" we use Barclays Capital Indices (US Government/Credit, Global Aggregate Ex USA, US MBS and Hedge Fund (Asset Weighted), respectively). We get the returns to cash and equivalents from Ken French's website

(one month risk-free rate). For the return to private equity we use the mid-point of the range estimated by Steven N. Kaplan (private conversation).

Asset-Weighted Average Asset Allocation

Latest Annual Financial Reports

June 2008 Reports $(\mathrm{N}=66)$

December 2007 Reports $(\mathrm{N}=16)$

June 2007 Reports ( $\mathrm{N}=22$ )

Pensions \& Investments, September 2008



Returns Used to Calculate Totals

September 2008 to December 2008

June 2008 to December 2008

December 2007 to December 2008

\begin{tabular}{|c|c|c|c|c|c|c|c|c|}
\hline \multicolumn{9}{|c|}{ Returns } \\
\hline $\begin{array}{r}\text { Domestic } \\
\text { Stock }\end{array}$ & $\begin{array}{r}\text { International } \\
\text { Stock }\end{array}$ & $\begin{array}{r}\text { Domestic } \\
\text { Fixed } \\
\text { Income }\end{array}$ & $\begin{array}{l}\text { International } \\
\text { Fixed Income }\end{array}$ & $\begin{array}{r}\text { Cash and } \\
\text { Equivalents }\end{array}$ & $\begin{array}{l}\text { Private } \\
\text { Equity }\end{array}$ & $\begin{array}{r}\text { Real } \\
\text { Estate } \\
\text { Equity }\end{array}$ & Mortgages & Other \\
\hline$-22.8 \%$ & $-21.5 \%$ & $2.7 \%$ & $5.7 \%$ & $0.2 \%$ & $-12.5 \%$ & $-39.1 \%$ & $-15.0 \%$ & $-7.4 \%$ \\
\hline$-30.1 \%$ & $-38.1 \%$ & $1.5 \%$ & $-0.6 \%$ & $0.6 \%$ & $-17.8 \%$ & $-35.8 \%$ & $-20.3 \%$ & $-17.8 \%$ \\
\hline$-38.6 \%$ & $-45.2 \%$ & $2.4 \%$ & $4.4 \%$ & $1.6 \%$ & $-18.1 \%$ & $-38.0 \%$ & $-22.7 \%$ & $-18.1 \%$ \\
\hline
\end{tabular}




\section{Internet Appendix Table III: Actuarial Assumptions}

This table sets out the actuarial assumptions we use to translate among different liability methods and discount rates. Panel A, which simply shows member counts and average salaries for plans by actuarial method, was calculated using data from the Center for Retirement Research (2006) and the CAFRs of the 116 sample plans. For Panels B, $\mathrm{C}$, and $\mathrm{D}$, we examined the CAFRs of the 10 states with the largest total liabilities and took the assumptions from the reports where they were usable: New York, Illinois, Pennsylvania, Ohio, and Texas. The figures represent an average over the reports. Our model assumes that all job leavers leave with vested pension benefits, and that benefits are adjusted to be taken at a normal retirement age of 65 in an actuarially fair way. Where necessary we perform linear interpolations between age brackets.

A. Member Counts and Average Salary by Plan Actuarial Method for 2006

\begin{tabular}{|c|c|c|c|c|c|}
\hline & \multicolumn{4}{|c|}{ Member Counts (Millions of People) } & \multirow{3}{*}{$\begin{array}{c}\text { Average } \\
\text { Salary }\end{array}$} \\
\hline & \multirow[b]{2}{*}{ Active } & \multicolumn{3}{|c|}{ Separated } & \\
\hline & & Annuitants & Vested & Total & \\
\hline All & 12.29 & 5.89 & 2.18 & 20.17 & $\$ 39,859$ \\
\hline Projected Unit Credit & 1.58 & 0.79 & 0.37 & 2.75 & $\$ 43,483$ \\
\hline Entry Age Normal and Related & 10.70 & 5.10 & 1.81 & 17.42 & $\$ 39,323$ \\
\hline
\end{tabular}

B. Service Distribution of Job Leavers

\begin{tabular}{rrr} 
Min Years & Max Years & Distribution \\
\hline 5 & 10 & $8.1 \%$ \\
11 & 15 & $10.6 \%$ \\
16 & 20 & $11.5 \%$ \\
21 & 25 & $15.1 \%$ \\
26 & 30 & $18.5 \%$ \\
30 & 100 & $36.2 \%$
\end{tabular}

C. Salary Growth and Separation Rate by Age

\begin{tabular}{ccc} 
Age & Salary Growth & Separation Rate \\
\hline $21-25$ & $10.0 \%$ & $19.8 \%$ \\
$26-30$ & $11.2 \%$ & $9.1 \%$ \\
$31-35$ & $7.6 \%$ & $6.8 \%$ \\
$36-40$ & $7.0 \%$ & $6.0 \%$ \\
$41-45$ & $6.1 \%$ & $4.9 \%$ \\
$46-50$ & $5.6 \%$ & $4.7 \%$ \\
$51-55$ & $5.0 \%$ & $4.7 \%$ \\
$56-60$ & $4.7 \%$ & $21.4 \%$ \\
$61-65$ & $4.2 \%$ & $23.3 \%$ \\
$66-70$ & $4.0 \%$ & $26.1 \%$ \\
$71-75$ & $4.1 \%$ & $54.9 \%$
\end{tabular}


D. Age-Service Matrices

i.) Age-Service Weights (share of workforce in a given age-service bracket)

\begin{tabular}{rr}
\multicolumn{2}{c}{ Age } \\
\hline Min & Max \\
\hline 21 & 25 \\
26 & 30 \\
31 & 35 \\
36 & 40 \\
41 & 45 \\
46 & 50 \\
51 & 55 \\
56 & 60 \\
61 & 65 \\
66 & 70 \\
71 & 75
\end{tabular}

\begin{tabular}{rrrr}
\hline $0-5$ & $6-10$ & $11-15$ & $16-20$ \\
\hline 0.033 & 0.000 & & \\
0.108 & 0.021 & 0.000 & \\
0.053 & 0.068 & 0.010 & 0.000 \\
0.038 & 0.042 & 0.044 & 0.007 \\
0.036 & 0.027 & 0.024 & 0.027 \\
0.032 & 0.027 & 0.019 & 0.018 \\
0.023 & 0.024 & 0.022 & 0.019 \\
0.014 & 0.015 & 0.017 & 0.020 \\
0.007 & 0.005 & 0.006 & 0.007 \\
0.001 & 0.001 & 0.001 & 0.001 \\
0.001 & 0.000 & 0.000 & 0.000
\end{tabular}

Years of Service

\begin{tabular}{lllllll}
$21-25$ & $26-30$ & $31-35$ & $36-40$ & $41-45$ & $46-50$ & $51-55$ \\
\hline 0.000 & & & & & & \\
0.006 & 0.000 & & & & & \\
0.023 & 0.006 & 0.001 & & & & \\
0.018 & 0.028 & 0.013 & 0.000 & & & \\
0.018 & 0.016 & 0.026 & 0.004 & 0.000 & & \\
0.007 & 0.005 & 0.004 & 0.003 & 0.000 & & \\
0.001 & 0.001 & 0.001 & 0.000 & 0.000 & 0.000 & \\
0.000 & 0.000 & 0.000 & 0.000 & 0.000 & 0.000 & 0.000
\end{tabular}

ii.) Age-Service Relative Wages (as a fraction of overall average wage)

\begin{tabular}{|c|c|c|c|c|c|c|c|c|c|c|c|c|}
\hline \multicolumn{2}{|c|}{ Age } & \multicolumn{11}{|c|}{ Years of Service } \\
\hline Min & Max & $0-5$ & $6-10$ & $11-15$ & $16-20$ & $21-25$ & $26-30$ & $31-35$ & $36-40$ & $41-45$ & $46-50$ & $51-55$ \\
\hline 21 & 25 & 0.570 & 0.441 & & & & & & & & & \\
\hline 26 & 30 & 0.698 & 0.844 & 0.767 & & & & & & & & \\
\hline 31 & 35 & 0.718 & 0.911 & 0.882 & 0.695 & & & & & & & \\
\hline 36 & 40 & 0.655 & 0.899 & 1.069 & 1.123 & 1.020 & & & & & & \\
\hline 41 & 45 & 0.603 & 0.804 & 1.037 & 1.174 & 1.204 & 0.948 & & & & & \\
\hline 46 & 50 & 0.588 & 0.746 & 0.927 & 1.125 & 1.245 & 1.253 & 0.959 & & & & \\
\hline 51 & 55 & 0.610 & 0.761 & 0.906 & 1.056 & 1.215 & 1.325 & 1.367 & 1.344 & & & \\
\hline 56 & 60 & 0.659 & 0.772 & 0.903 & 1.043 & 1.168 & 1.307 & 1.413 & 1.478 & 1.352 & & \\
\hline 61 & 65 & 0.686 & 0.745 & 0.868 & 0.998 & 1.119 & 1.202 & 1.318 & 1.491 & 1.461 & & \\
\hline 66 & 70 & 0.760 & 0.848 & 0.911 & 1.011 & 1.083 & 1.164 & 1.241 & 1.345 & 1.429 & 1.160 & \\
\hline 71 & 75 & 0.718 & 0.722 & 0.540 & 0.764 & 0.878 & 0.880 & 1.132 & 1.301 & 1.172 & 1.358 & 1.276 \\
\hline
\end{tabular}


Internet Appendix Table IV: Government Employee Wage Data and the Stock Market

\begin{tabular}{|c|c|c|c|c|c|c|c|c|}
\hline CPS Year & $\begin{array}{c}\text { Mean } \\
\text { Wage } \\
\text { Income }\end{array}$ & $\begin{array}{c}\text { Standard } \\
\text { Deviation } \\
\text { of Wage } \\
\text { Income }\end{array}$ & $\begin{array}{l}\text { Growth in } \\
\text { Mean } \\
\text { Wage } \\
\text { Income }\end{array}$ & $\begin{array}{c}\text { CPI } \\
\text { Inflation } \\
\end{array}$ & $\begin{array}{c}\text { Government } \\
\text { Wage Growth } \\
\text { Minus CPI } \\
\text { Inflation } \\
\end{array}$ & $\begin{array}{c}\text { Risk free } \\
\text { rate }\left(r_{f}\right)\end{array}$ & $\begin{array}{c}\text { Stock } \\
\text { Market } \\
\text { Return } \\
\left(r_{m}\right) \\
\end{array}$ & $\begin{array}{l}\text { Excess } \\
\text { Return } \\
\left(r_{m}-r_{f}\right) \\
\end{array}$ \\
\hline 1962 & 5000 & 2724 & & & & $2.7 \%$ & $-10.3 \%$ & $-13.1 \%$ \\
\hline 1963 & 5033 & 2446 & $0.7 \%$ & $1.3 \%$ & $-0.7 \%$ & $3.1 \%$ & $20.9 \%$ & $17.8 \%$ \\
\hline 1964 & 5327 & 2881 & $5.8 \%$ & $1.3 \%$ & $4.5 \%$ & $3.5 \%$ & $16.3 \%$ & $12.8 \%$ \\
\hline 1965 & 5471 & 2632 & $2.7 \%$ & $1.6 \%$ & $1.1 \%$ & $3.9 \%$ & $14.4 \%$ & $10.5 \%$ \\
\hline 1966 & 5791 & 3159 & $5.9 \%$ & $2.9 \%$ & $3.0 \%$ & $4.8 \%$ & $-8.7 \%$ & $-13.4 \%$ \\
\hline 1967 & 6023 & 2874 & $4.0 \%$ & $3.1 \%$ & $0.9 \%$ & $4.2 \%$ & $28.6 \%$ & $24.4 \%$ \\
\hline 1968 & 6598 & 3699 & $9.6 \%$ & $4.2 \%$ & $5.4 \%$ & $5.2 \%$ & $14.2 \%$ & $9.0 \%$ \\
\hline 1969 & 7148 & 4188 & $8.3 \%$ & $5.5 \%$ & $2.9 \%$ & $6.6 \%$ & $-10.8 \%$ & $-17.4 \%$ \\
\hline 1970 & 7734 & 3686 & $8.2 \%$ & $5.7 \%$ & $2.5 \%$ & $6.5 \%$ & $0.1 \%$ & $-6.4 \%$ \\
\hline 1971 & 8446 & 4279 & $9.2 \%$ & $4.4 \%$ & $4.8 \%$ & $4.4 \%$ & $16.2 \%$ & $11.8 \%$ \\
\hline 1972 & 8814 & 5184 & $4.4 \%$ & $3.2 \%$ & $1.2 \%$ & $3.8 \%$ & $17.3 \%$ & $13.5 \%$ \\
\hline 1973 & 9357 & 4777 & $6.2 \%$ & $6.2 \%$ & $-0.1 \%$ & $6.9 \%$ & $-18.8 \%$ & $-25.7 \%$ \\
\hline 1974 & 9977 & 5379 & $6.6 \%$ & $11.0 \%$ & $-4.4 \%$ & $8.0 \%$ & $-27.9 \%$ & $-36.0 \%$ \\
\hline 1975 & 10556 & 5762 & $5.8 \%$ & $9.1 \%$ & $-3.3 \%$ & $5.8 \%$ & $37.4 \%$ & $31.6 \%$ \\
\hline 1976 & 11499 & 5646 & $8.9 \%$ & $5.8 \%$ & $3.2 \%$ & $5.1 \%$ & $26.8 \%$ & $21.7 \%$ \\
\hline 1977 & 12248 & 5944 & $6.5 \%$ & $6.5 \%$ & $0.0 \%$ & $5.1 \%$ & $-3.0 \%$ & $-8.1 \%$ \\
\hline 1978 & 12924 & 6336 & $5.5 \%$ & $7.6 \%$ & $-2.1 \%$ & $7.2 \%$ & $8.6 \%$ & $1.4 \%$ \\
\hline 1979 & 13829 & 7108 & $7.0 \%$ & $11.3 \%$ & $-4.3 \%$ & $10.4 \%$ & $24.4 \%$ & $14.0 \%$ \\
\hline 1980 & 14879 & 8008 & $7.6 \%$ & $13.5 \%$ & $-5.9 \%$ & $11.3 \%$ & $33.2 \%$ & $22.0 \%$ \\
\hline 1981 & 16236 & 7193 & $9.1 \%$ & $10.3 \%$ & $-1.2 \%$ & $14.7 \%$ & $-4.0 \%$ & $-18.7 \%$ \\
\hline 1982 & 17813 & 7941 & $9.7 \%$ & $6.2 \%$ & $3.6 \%$ & $10.5 \%$ & $20.4 \%$ & $9.9 \%$ \\
\hline 1983 & 18333 & 9481 & $2.9 \%$ & $3.2 \%$ & $-0.3 \%$ & $8.8 \%$ & $22.7 \%$ & $13.9 \%$ \\
\hline 1984 & 19926 & 10540 & $8.7 \%$ & $4.3 \%$ & $4.4 \%$ & $9.8 \%$ & $3.2 \%$ & $-6.7 \%$ \\
\hline 1985 & 21048 & 11155 & $5.6 \%$ & $3.6 \%$ & $2.1 \%$ & $7.7 \%$ & $31.4 \%$ & $23.7 \%$ \\
\hline 1986 & 21657 & 11127 & $2.9 \%$ & $1.9 \%$ & $1.0 \%$ & $6.2 \%$ & $15.6 \%$ & $9.4 \%$ \\
\hline 1987 & 23038 & 11824 & $6.4 \%$ & $3.6 \%$ & $2.7 \%$ & $5.5 \%$ & $1.8 \%$ & $-3.7 \%$ \\
\hline 1988 & 24311 & 12388 & $5.5 \%$ & $4.1 \%$ & $1.4 \%$ & $6.4 \%$ & $17.6 \%$ & $11.2 \%$ \\
\hline 1989 & 25143 & 12972 & $3.4 \%$ & $4.8 \%$ & $-1.4 \%$ & $8.4 \%$ & $28.4 \%$ & $20.1 \%$ \\
\hline 1990 & 26749 & 13631 & $6.4 \%$ & $5.4 \%$ & $1.0 \%$ & $7.8 \%$ & $-6.1 \%$ & $-13.9 \%$ \\
\hline 1991 & 27400 & 13880 & $2.4 \%$ & $4.2 \%$ & $-1.8 \%$ & $5.6 \%$ & $33.6 \%$ & $28.0 \%$ \\
\hline 1992 & 29008 & 14717 & $5.9 \%$ & $3.0 \%$ & $2.9 \%$ & $3.5 \%$ & $9.1 \%$ & $5.6 \%$ \\
\hline 1993 & 30067 & 15131 & $3.7 \%$ & $3.0 \%$ & $0.7 \%$ & $2.9 \%$ & $11.6 \%$ & $8.7 \%$ \\
\hline 1994 & 30719 & 15738 & $2.2 \%$ & $2.6 \%$ & $-0.4 \%$ & $3.9 \%$ & $-0.8 \%$ & $-4.7 \%$ \\
\hline 1995 & 31699 & 16922 & $3.2 \%$ & $2.8 \%$ & $0.4 \%$ & $5.6 \%$ & $35.7 \%$ & $30.1 \%$ \\
\hline 1996 & 33301 & 24617 & $5.1 \%$ & $3.0 \%$ & $2.1 \%$ & $5.2 \%$ & $21.2 \%$ & $16.0 \%$ \\
\hline 1997 & 33627 & 22699 & $1.0 \%$ & $2.3 \%$ & $-1.3 \%$ & $5.3 \%$ & $30.3 \%$ & $25.1 \%$ \\
\hline 1998 & 34860 & 21563 & $3.7 \%$ & $1.6 \%$ & $2.1 \%$ & $4.9 \%$ & $22.3 \%$ & $17.4 \%$ \\
\hline 1999 & 36204 & 21813 & $3.9 \%$ & $2.2 \%$ & $1.6 \%$ & $4.7 \%$ & $25.3 \%$ & $20.6 \%$ \\
\hline 2000 & 37003 & 21555 & $2.2 \%$ & $3.4 \%$ & $-1.2 \%$ & $5.9 \%$ & $-11.1 \%$ & $-16.9 \%$ \\
\hline 2001 & 39358 & 24954 & $6.4 \%$ & $2.8 \%$ & $3.5 \%$ & $3.9 \%$ & $-11.3 \%$ & $-15.1 \%$ \\
\hline 2002 & 40366 & 25560 & $2.6 \%$ & $1.6 \%$ & $1.0 \%$ & $1.6 \%$ & $-20.8 \%$ & $-22.5 \%$ \\
\hline 2003 & 41402 & 28042 & $2.6 \%$ & $2.3 \%$ & $0.3 \%$ & $1.0 \%$ & $33.1 \%$ & $32.1 \%$ \\
\hline 2004 & 43600 & 30343 & $5.3 \%$ & $2.7 \%$ & $2.6 \%$ & $1.2 \%$ & $13.0 \%$ & $11.8 \%$ \\
\hline 2005 & 43281 & 27485 & $-0.7 \%$ & $3.4 \%$ & $-4.1 \%$ & $3.0 \%$ & $7.3 \%$ & $4.4 \%$ \\
\hline 2006 & 45182 & 33045 & $4.4 \%$ & $3.2 \%$ & $1.2 \%$ & $4.8 \%$ & $16.2 \%$ & $11.4 \%$ \\
\hline 2007 & 45969 & 30834 & $1.7 \%$ & $2.8 \%$ & $-1.1 \%$ & $4.7 \%$ & $7.3 \%$ & $2.6 \%$ \\
\hline 2008 & 47416 & 29402 & $3.1 \%$ & $3.8 \%$ & $-0.7 \%$ & $1.6 \%$ & $-38.3 \%$ & $-40.0 \%$ \\
\hline Mean & & & $5.0 \%$ & $4.8 \%$ & $0.6 \%$ & $5.7 \%$ & $11.0 \%$ & $5.3 \%$ \\
\hline Volatility & & & $2.6 \%$ & $3.1 \%$ & $2.6 \%$ & $2.8 \%$ & $17.9 \%$ & $17.9 \%$ \\
\hline
\end{tabular}




\section{Internet Appendix Technical Note 1: Estimating Public Pension Assets as of December 2008}

We collected asset and asset allocation data from the Pensions and Investments survey for all state pension investment funds. The latest survey, published in January 2009, contains data for 30 September 2008. Due to the fact that some states use one fund for multiple plans, there were 71 investment funds that covered our 116 sample plans. The P\&I asset allocation data decomposes assets into 9 categories: Domestic Stock, International Stock, Domestic Fixed Income, International Fixed Income, Cash and Equivalents, Private Equity, Real Estate Equity, Mortgages, and Other. For these categories we obtained return indices for September 2008 through December 2008 from the Kenneth R. French Data Library (the Fama-French factors), Barra MSCI, and Lehman Brothers / Barclays. Using P\&I data and these asset class returns, we were able to project plan assets forward to December 2008, arriving at a value of $\$ 1.94$ trillion. The asset allocation figures are shown in Internet Appendix Table II. They bear similarity to the tabulations in Rauh (2008) of corporate pension plans, in which total allocations to equity among major pension sponsors as of the end of 2003 were approximately $60 \%$.

The P\&I data had the advantage of being harmonized to one date. However, they are survey data, whose quality is likely worse than the audited CAFRs. We therefore collected asset allocation data from the CAFRs as well, compiled them into the same 9 categories, and used the category return indices over the applicable dates to project all the assets forward to December 2008. From this exercise we arrived at a similar asset value of $\$ 2.02$ trillion. While based on higher quality data, this method required us to project assets using the aggregated asset class return assumptions over a longer period.

Where we occasionally refer in the paper to the difference between assets and liabilities, we use the $\$ 1.94$ trillion projection based on the more recent survey of assets instead of the $\$ 2.02$ trillion based on the older CAFR assets, although the difference of $\$ 80$ billion is minor in this context.

\section{Internet Appendix Technical Note 2: Normal Costs Under the Entry Age Normal Accrual Method}

To see that the EAN accruals resemble money set aside in a DC saving plan, note that under the EAN method the Normal Cost for a worker of age $a$ with $s$ years of service, i.e., the liability accrued for the current year of service, is given by

$$
N C_{-} E A N_{a, s}^{T}=E A N_{a, s}^{T}-\left(\frac{1+r}{S_{a-1,1}}\right) \times E A N_{a-1, S-1}^{T+1},
$$

the difference between the current liability and last year's liability grossed up by the discount rate and adjusted to account for the fact that the worker survived from last year. Substituting our formula for the EAN into the previous equation and simplifying yields 


$$
N C_{-} E A N_{a, s}^{T}=\left(\frac{P V B_{a-s, 0}^{s+T}}{\sum_{i=1}^{s+T} \frac{S_{a-s, i}}{(1+r)^{i}} \times W_{a-s+i, i}}\right) \times W_{a, s} .
$$

The term in the parentheses on the right hand side of the previous equation is unchanged if $a$ and $s$ increase by one while $T$ decreases by one. That is, it is invariant over the employee's tenure. 